\title{
The Role of Exosomal MicroRNAs in the Tumor Microenvironment of Breast Cancer
}

\author{
Qingqing Liu ${ }^{1,2}$, Fu Peng ${ }^{1,2,3}$ and Jianping Chen ${ }^{1,2, *}$ \\ 1 School of Chinese Medicine, Li Ka Shing Faculty of Medicine, The University of Hong Kong, \\ Pokfulam 999077, Hong Kong, China \\ 2 HKU Shenzhen Institute of Research and Innovation, Shenzhen 518057, China \\ 3 West China School of Pharmacy, Sichuan University, Chengdu 610041, China \\ * Correspondence: abchen@hku.hk; Tel.: +852-3917-6479
}

Received: 26 April 2019; Accepted: 6 August 2019; Published: 9 August 2019

check for updates

\begin{abstract}
Breast cancer, ranking first among women's cancers worldwide, develops from the breast tissue. Study of the breast tissue is, therefore of great significance to the diagnosis and treatment of breast cancer. Exosomes, acting as an effective communicator between cells, are in the ascendant in recent years. One of the most important cargoes contained in the exosomes is microRNAs, belonging to the non-coding RNA family. When the exosomal microRNAs are absorbed into the intracellular location, most of the microRNAs will act as tumor promoters or suppressors by inhibiting the translation process of the target mRNA, thus affecting the behavior of other stromal cells in the tumor microenvironment. At present, growing research focuses on the different types of donor cell sources, their contribution to cancer, miRNA profiling, their biomarker potential, etc. This review aims to state the function of diverse miRNAs in exosomes medicated cell-cell communication and the potency of some specific enriched miRNAs as molecular markers in clinical trials. We also describe the mechanism of anti-cancer compounds through exosomes and the exploration of artificially engineered techniques that lead miRNA-inhibitors into exosomes for therapeutic use.
\end{abstract}

Keywords: breast cancer; tumor microenvironment; exosomes; microRNA; biomarker

\section{Introduction}

\subsection{Breast Cancer}

Breast cancer is one of the most common female malignant tumors and threatens the physical and psychological health of women around the world. About 1.3 million cases of mammary cancer worldwide are diagnosed and 450,000 people's lives are being taken every year [1]. Moreover, it was reported by the American Cancer Society that breast cancer ranked first in the incidence rate among American women's cancer between 1975 and 2014 [2], ranking second in mortality (after lung cancer) [3]. According to the latest report, there were approximately 268,670 new breast cancer patients in 2018 in the United States, which resulted in 40,000 deaths [2].

Breast carcinoma is a complex disease of morphological and molecular heterogeneity, characterized by three morphological grades and over four different molecular subtypes (at the gene expression level) [4]. According to the consensus reached at the St. Gallen International Expert Conference of breast cancer in 2015 and 2017 [5,6], breast cancer was clinically classified into four major subtypes: triple negative, hormone receptor (HR)-negative and human epidermal growth factor receptor 2 (HER2)-positive, HR-positive and HER2-positive, HR-positive and HER2-negative (Table 1). For different types of breast tumors, there are great differences in the treatment options. 
Table 1. Subtypes of breast tumor (summarized from St. Gallen conference of 2015 and 2017).

\begin{tabular}{|c|c|c|c|}
\hline Subtypes & Classification & HER2 & HR \\
\hline Triple negative & TNBC $^{1}$ & $(-)$ & $\mathrm{ER}^{2}(-), \operatorname{PgR}^{3}(-)$ \\
\hline HR $(-)$ and HER2 (+) & \multirow{2}{*}{ HER2-positive } & $(+)$ & $\mathrm{ER}(-), \operatorname{PgR}(-)$ \\
\hline HR $(+)$ and HER2 (+) & & $(+)$ & ER and/or PgR (+) \\
\hline \multirow{3}{*}{$\mathrm{HR}(+)$ and HER2 (-) } & Luminal-A like & $(-)$ & $\begin{array}{c}\text { ER and/or PgR (+); Multi-parameter molecular } \\
\text { marker 'good' if available; High ER/PR; clearly } \\
\text { low Ki-67 (low proliferation [7]); low grade } \\
\text { (well-differentiated [8]) }\end{array}$ \\
\hline & Intermediate & $(-)$ & $\begin{array}{l}\text { Multi-parameter molecular marker 'intermediate' } \\
\text { if available. }\end{array}$ \\
\hline & Luminal-B like & $(-)$ & $\begin{array}{l}\text { ER and/or PgR (+); Multi-parameter molecular } \\
\text { marker 'bad' if available; Lower ER/PR; clearly } \\
\text { high Ki-67 (high proliferation [7]); histological } \\
\text { grade } 3 \text { (poorly differentiated [8]) }\end{array}$ \\
\hline
\end{tabular}

${ }^{1} \mathrm{TNBC}$, triple negative breast cancer; ${ }^{2} \mathrm{ER}$, estrogen receptor; ${ }^{3} \mathrm{PgR}$, progesterone receptor.

\subsection{Tumor Microenvironment (TME)}

As known to us all, the constant growth of tumor metastasis is responsible for most cancer deaths [9]. Since Paget first proposed the famous 'seed and soil' hypothesis (1989), the relationship between the microenvironment and the tumor has caused widespread concern that tumor metastasis was not an accidental event, it happened only when those cancer cells with potential to metastasize (the 'seed') were compatible and familiar with proper organ microenvironment (the 'soil') [9-11]. The TME often refers to an area that is close to the existence of the solid tumor. Apart from breast cancer cells, the TME also contains plenty of other different types of cells including vascular endothelial cells (VECs), cancer-associated fibroblasts (CAFs), immune cells like tumor-associated macrophages (TAMs), myeloid-derived suppressor cell (MDSCs), T lymphocytes, B lymphocytes, as well as myoepithelial cells, adipocytes, etc. Moreover, some non-cellular components are also involved, covering the extracellular matrix (ECM), exosomes, soluble cytokines or signaling molecules [12,13]. It is worth noting that the physical characteristics of the tumor microenvironment are also different from normal tissues, such as hypoxia, acidity, high interstitial fluid pressure [13,14].

Cancer-associated fibroblasts (CAFs), which are considered as 'activated fibroblasts', constitute a major intracellular component of tumor stroma in the microenvironment [15]. CAFs can be derived from quiescent fibroblasts with altered phenotype and effects [16], epithelial cells through the epithelial-mesenchymal transition (EMT) [15-17], endothelial cells through the endothelialmesenchymal transition (EndMT) [17,18], bone marrow-derived cells [19,20], and so on [18]. Through the secretion of different types of cytokines and growth factors, CAFs can have interactions with cancer cells, inflammatory cells, and other various cells and affect the occurrence and progression of tumors. For example, CAFs can secrete stromal-cell-derived factor 1 (SDF-1/CXCL12) [21], vascular endothelial growth factor (VEGF) [22], platelet-derived growth factor (PDGF) [18], fibroblast growth factor (FGF) [23], etc., to induce angiogenesis and promote tumor cells' proliferation; degrade and remodel ECM by producing the members of matrix metalloproteinase family (MMPs) [24], resulting in the decrease of the ability of cell adhesion and contribute to metastasis. There are certain effects on the local immunity of tumors [16] by secreting interleukin-6 (IL-6), IL-10, IL-8, C-X-C motif chemokine ligand 9 (CXCL9), CXCL10, etc.

As described by Kalluri et al. [15], tumors can also be seen as a wound, accompanying inflammatory reactions. Different immune cells in the tumor microenvironment have different effects, thus creating a balance between carcinogenesis and tumor suppressor. Tumor-associated macrophages (TAMs) belong to bone marrow-derived cells with important roles in innate and adaptive immunity [25]. They are very abundant and highly infiltrating in the tumor microenvironment, and the richer density the macrophages, the worse the prognosis of patients [26]. TAMs can be derived from the 
following types of cells: blood monocytes, blood monocyte-related myeloid-derived suppressor cells, tissue-resident macrophages [27]. They can be recruited to tumor sites by cytokines (colony-stimulating factor-1(CSF1), chemokine (C-C motif) ligand 2 (CCL2), CCL5, etc.), and differentiate into TAMs [27]. Generally speaking, there are two subtypes of TAMs - classically (M1)- and alternatively-activated (M2) macrophages [12]. M1 macrophages have antineoplastic effect with the function of secreting tumor necrosis factor- $\alpha$ (TNF- $\alpha$ ), IL-23, IL-12, etc., while M2 phenotype will express IL-10, CCL20, transforming growth factor- $\beta$ (TGF- $\beta$ ), etc., to promote tumor [28]. In addition, TAMs can excrete cytokines such as epidermal growth factor (EGF), PDGF, VEGF, CCL2, CXCL8 to promote angiogenesis [29]; participate in CSF1 (secreted from breast cancer cell) and EGF (contributed by activated macrophages) feedback loop to cause metastasis [29]; and accumulate in hypoxic area [26].

In brief, it must be emphasized that tumor microenvironment is critical for tumor behaviors: occurrence, progression, invasion and metastasis, prognosis and drug resistance $[29,30]$.

\subsection{Exosomes}

Exosomes, a branch of extracellular vesicles (EVs), are encased in cell membranes made up of lipid bilayers with a diameter of 30-100 $\mathrm{nm}$ and cup-shape appearance [31,32]. Almost all eukaryotic cells can secrete exosomes, including tumor cells and normal stromal cells, but it is reported that cancer cells express more exosomes than normal proliferation cells [32,33].

The biogenesis of exosomes [34-36] mainly consists of the following steps: (1) cell endocytosis: inward depression to form early endosome and enclose some intracytoplasmic contents (2) gradually mature to form late endosomes, also known as intracellular multivesicular bodies (MVBs); and (3) the MVBs will be degraded by lysosome or recycled by fusing with the plasma membrane and releasing the intraluminal vesicles (ILVs), namely exosomes. Interestingly, different cells may select different contents into exosomes, but the selection mechanisms need to be further explored [34]. Accordingly, exosome has various surface receptors, including lipids (phosphatidylserine), sialoadhesin (CD169), tetraspanins (CD9, CD63, CD81, etc.), antigen presentation (MHC I, MHC II), and adhesion molecules (integrins, lactadherin, etc.) [36]. There are also several main mechanisms for the process of recipient cells' uptake [37]: (1) the T cell receptor- major histocompatibility complex (MHC) interaction; (2) fusion with membrane of recipient cells; (3) cell phagocytosis; and (4) adhesion molecules interaction.

Recently, exosomes have come under increasing interest from researchers, mainly because they have been found to wrap many biomolecules, such as DNAs, mRNAs, non-coding gene family (microRNA, IncRNA), proteins, and lipids [38]. Carrying these active biomolecules, exosomes have also been found to circulate in body fluids, such as blood (plasma or serum), urine, feces, breast milk and saliva, so that exosomes are able to transmit intercellular regulatory information to the both surrounding and distant sites, which indicates the potential to be non-invasive biomarkers [39]. Increasing articles of exosomes reported extensive involvement in physiological and pathological processes, such as placental physiology [40], angiogenesis and increased heart function [41], endometrial-embryo interactions [42], and pituitary tumors [43]. Here, we mainly focus on the role of exosomes in breast cancer.

\subsection{MicroRNAs}

In 1993, Lee et al. reported the first discovery of miRNA that gene lin-4 encoded small RNA molecules to regulate the expression of protein lin-14 in Caenorhabditis elegans [44]. MicroRNAs (miRNAs) are small RNA molecules with single chains that do not encode proteins. They usually have a length of about 19 and 25 nucleotides, most of which negatively regulate the post-transcriptional level of target messenger ribonucleic acids (mRNAs) by binding to the $3^{\prime}$-untranslated region (UTR) [45]. Three possible mechanisms may be involved in the process: repression of translation initiation, post-initiation inhibition and target mRNA destabilization, resulting in the degradation of mRNA or translation inhibition [46].

In recent years, numerous studies have shown that varieties of microRNAs function in direct or indirect interactions between breast cancer cells and components of TME $[47,48]$. For example, 
miR-373 and miR-520c can raise the invasion and metastasis of tumor by inhibiting metastasis-related gene CD44 [49]. Moreover, miRNAs can be circulated in body fluid and the expression of miRNAs in peripheral blood may be used as a biological marker for the differential diagnosis and prognosis of breast tumors $[7,39]$. Exosomal miRNA profiling analyses were reported and compared, such as between drug-resistant and non-drug-resistant cells [50,51], normal mammary epithelial cells (MCF-10A) and MCF-7 [52], ER-positive (MCF-7) and triple negative (MDA-MB-231) cancer cell lines [53], HER2-positive and triple negative cancer patients [54], from canine mammary cells [55]. Liu et al. [56] integrated small RNA sequencing information of 17 diseases and built up an open EVmiRNA database for public searching of miRNA profiles.

This review mainly focuses on the bioactivity and underlying mechanism of exosomal microRNAs in the change of tumor microenvironment during the initiation and development of breast cancer.

\section{The Role of miRNAs in Exosomes in the Intercellular Crosstalk}

\subsection{Exosomes from Cancer Cells Can Provide MicroRNAs to Modify the Stromal Cells in the Tumor Microenvironment for Their Own Advantage (Table 2)}

The synthesis of microRNAs may occur in extracellular microvesicles. Melo et al. [57] reported that exosomes derived from mammary tumor cells (MDA-MB-231, MCF-7, 4T1) can specifically aggregate pre-miRNAs, as well as other proteins of the RISC complex, and then generate the mature miRNAs (up-regulated: miR-10a, -10b, -21, -27a, -155, -373) inside. When non-tumorigenic mammary epithelial cells (MCF-10A) and exosomes of tumor cells (MDA-MB-231) were co-cultured, the cancerization of normal cells was promoted, and Dicer enzyme (an important instrumental enzyme in the formation of mature miRNAs) could be seen as a controlling factor of this process. When MCF-10A was co-injected with exosomes derived from serum of breast cancer patients or healthy controls into nude mice, the former could form tumors with higher level of Dicer while the latter could not. Furthermore, exosomal miR-210 from tumor cells could transfer to endothelial cells to promote angiogenesis and metastasis and the secretion process of exosomes was also proved to be dependent on neutral sphingomyelinase 2 (nSMase2) enzyme (regulate ceramide biogenesis) [58,59]. Singh et al. [59] proved that nSMase2 or ceramide could promote the level of exosomal miR-10b, resulting in enhanced invasion ability of non-malignant cells by inhibiting the expression of homeobox D10 (HOXD10) [60] and KLF4. Other miRNAs such as miR-1246 [61] were also found to be secreted from breast cancer cells and change the behaviors of normal epithelial cells (Table 2).

Some highly metastatic/drug-resistant tumor cells can affect other tumor cell lines with low metastatic/non-drug resistance by secreting miRNAs in the exosomes, which is more convenient for their excessive growth. Different chemotherapeutic drugs-resistant MCF-7 cell lines were reported to secrete different miRNAs such as miR-222 [62,63], -23a [64], -100 [65], and -149 [66], etc., to non-drug-resistant cells to improve their resistance, leading to treatment failure (Table 2). In addition, some in vitro experiments also showed that after incubating purified exosomes from the metastatic cell line MDA-MB-231, the mobility and anchorage-independent ability (metastatic behaviors) of low metastatic MCF-7 cells were all increased and the underlying mechanism was related to exosomal miR-9 and miR-155 $[67,68]$. Genetically manipulated cells can also increase the level of specific microRNAs in exosomes and be absorbed by the original cell lines [69,70], which prompts a therapeutic direction.

Not only breast-related cells, but other stromal cells in the microenvironment can also uptake the external exosomes derived from the tumor cells, and then the contained miRNAs will be transported into them and affect their behavior, providing a favorable environment for the growth of the tumor (Figure 1). Exosome-mediated transfer of miR-105 [71] and miR-939 [72] could increase the permeability and destroy the integrity of vascular endothelial cells, leading to enhanced metastasis by targeting the zonula occludens 1 (ZO-1) gene and VE-cadherin, respectively. From data of clinical trials, exosomal miR-105 was proved to be associated with the incidence of metastasis [71]. Yan's study [73] also demonstrated that the level of miR-105 increase in the exosomes secreted from breast cancer cells was induced by oncogene MYC, and then transferred to CAFs. They also showed that miR-105 targeted 
at MAX-interacting protein 1 (MXI1) to activate MYC signaling and reprogram CAFs. Interestingly, whether under the circumstances of efficient nutrition or not, reprogrammed CAFs would ultimately promote tumor growth by leading to different metabolic pathways (glucose and glutamine metabolism with sufficient or metabolic waste decomposition, such as lactic acid and ammonium) and regulating the components of TME to provide energy to fuel cancer cells [73], which was similar to exosomal miR-122 transferred to lung fibroblasts and brain astrocytes [74]. In a recent study, after overexpressing miR-940 in breast cancer cells, treatment of human mesenchymal stem cells (MSCs) with exosomes contained culture medium- was shown to promote osteogenesis in vitro by acting on Rho GTPase-activating protein 1 (ARHGAP1) and family with sequence similarity 134, member A (FAM134A) [75]. The well-designed in vivo experiment also demonstrated that exosomes (labelled with CD63 (exosomes' marker) fused red fluorescent) were derived from miR-940 overexpressed cancer cells and absorbed by host cells (labelled with GFP) under confocal microscopy, which caused osteoblastic lesions by implanting cancer cells onto the calvarial bones/tibial sites of immunodeficient mice [75]. The growing expression of miR-770 (acting as a tumor suppressor, direct targets at STMN1) from TNBC cells to tumor-associated macrophages (TAMs) through exosome delivery modulated more differentiation to M1 phenotype instead of M2 phenotype and inhibited drug-resistance [76].

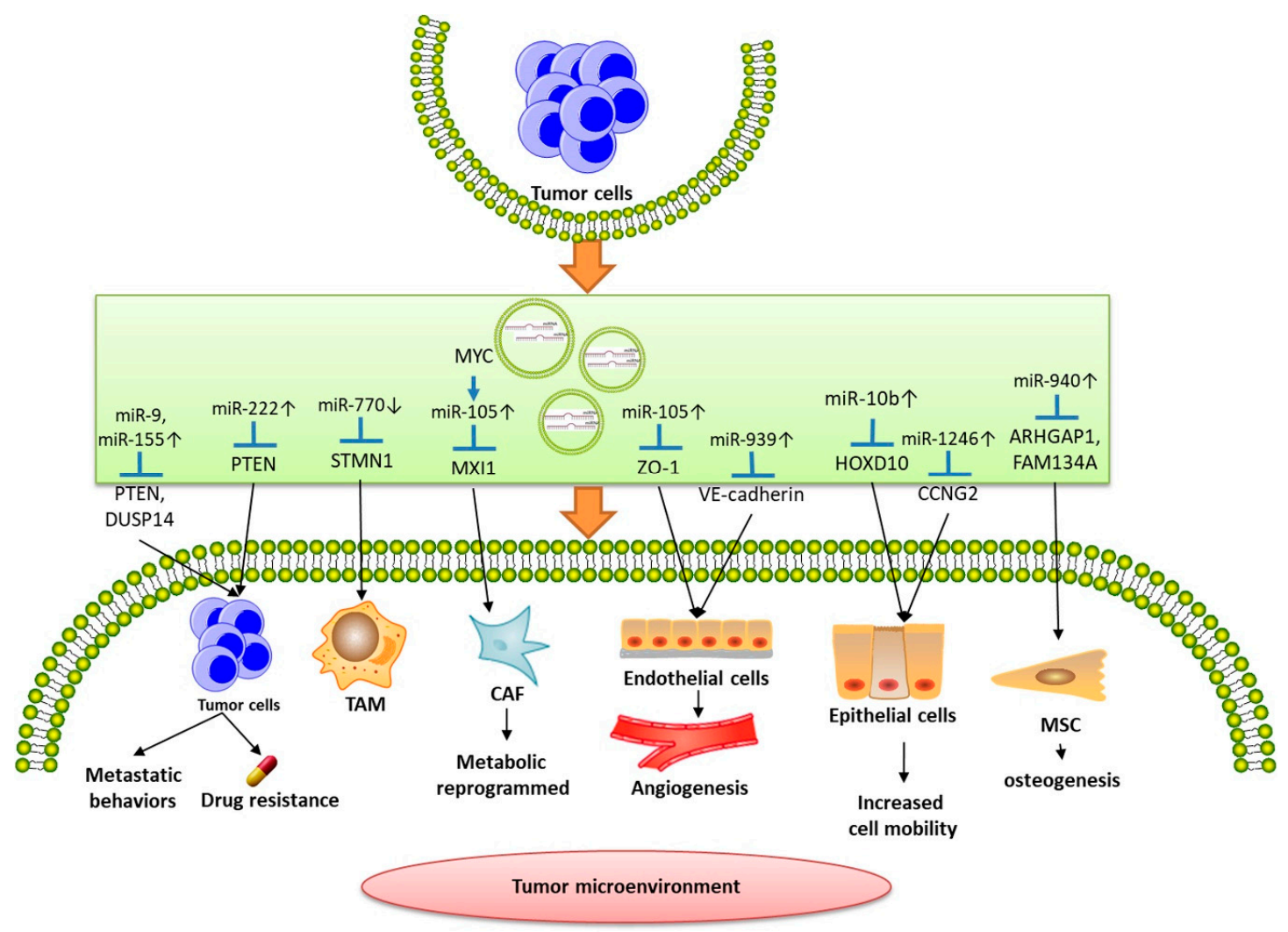

Figure 1. Tumor cells can secrete exosomes which contain diverse microRNAs to modify low-metastatic or non-resistant cancer cells and the stromal cells in the tumor microenvironment such as tumor-associated macrophages (TAMs), cancer-associated fibroblasts (CAFs), endothelial and epithelial cells, mesenchymal cells (MSCs) for their own advantage.

Cancer-produced exosomes may also be regulated by the physical conditions of microenvironment like hypoxia, an unignored feature of solid tumors that motivates tumor deterioration [77]. By using a miR-210 specific reporter system, elevated miR-210 was visually proved to be transferred from hypoxic cancer cells to proximal endothelial cells via exosomes both in vitro and in vivo, which may be interceded by hypoxia-inducible factor- $1 \alpha$ (HIF-1 $\alpha$ ) and restrain the expression of vascular remodeling related genes, like Ephrin A3 and PTP1B, to support angiogenesis and tumor growth [78,79]. 
Table 2. Evidence supporting a role for exosomal microRNAs in cancer cell-cell communication (from cancer cells).

\begin{tabular}{|c|c|c|c|c|c|c|c|}
\hline Stimulant & Cargo-microRNAs & Donor Cells & Recipient Cells & Gene Targets & $\begin{array}{l}\text { Biological } \\
\text { Activities }\end{array}$ & Major Findings & Refs \\
\hline & $\begin{array}{l}\operatorname{miR}-10 a, 10 b, 21 \\
27 a, 155,373(\uparrow)\end{array}$ & $\begin{array}{c}\text { Cancer cell } \\
\text { (MDA-MB-231, MCF-7, } \\
67 \mathrm{NR}, 4 \mathrm{~T} 1)\end{array}$ & $\begin{array}{l}\text { Epithelial cells } \\
\text { (MCF-10A, } \\
\text { NMuMG) }\end{array}$ & $\begin{array}{c}\text { HOXD10 } \\
\text { (miR-10b), PTEN } \\
(\mathrm{miR}-21)\end{array}$ & $\begin{array}{l}\text { Tumorigenesis (in } \\
\text { a Dicer-dependent } \\
\text { manner) }\end{array}$ & $\begin{array}{c}\text { Pre-miRNAs, Dicer } \\
\text { (CD43-mediated accumulation), } \\
\text { AGO2, and TRBP are present in } \\
\text { exosomes of cancer cells to } \\
\text { generate mature miRNAs. }\end{array}$ & [57] \\
\hline & $\operatorname{miR}-210(\uparrow)$ & $\begin{array}{l}\text { Cancer cell (4T1, MCF-7, } \\
\text { MDA-MB-231-D3H1, } \\
\text { MDA-MB-231-D3H2LN) }\end{array}$ & $\begin{array}{l}\text { Endothelial cells } \\
\text { (HUVECs) }\end{array}$ & ephrin-A3 & $\begin{array}{l}\text { Angiogenesis; } \\
\text { metastasis }\end{array}$ & $\begin{array}{l}\text { nSMase2 is important to } \\
\text { regulate exosomal miRNAs, } \\
\text { which will transfer to } \\
\text { endothelial cells to promote } \\
\text { metastatic initiation efficiency. }\end{array}$ & [58] \\
\hline \multirow[t]{4}{*}{ Twist } & $\operatorname{miR}-10 \mathrm{~b}(\uparrow)$ & $\begin{array}{c}\text { Cancer cell } \\
\text { (MDA-MB-231, MCF-7) }\end{array}$ & $\begin{array}{c}\text { Epithelial cells } \\
\text { (MCF-10A, HMLE) }\end{array}$ & $\begin{array}{l}\text { HOXD10 (inhibit } \\
\text { the expression of } \\
\text { the pro-metastatic } \\
\text { gene, RHOC), } \\
\text { KLF44 }\end{array}$ & Invasion & $\begin{array}{l}\text { nSMase } 2 \text { or ceramide promotes } \\
\text { the exosome-mediated } \\
\text { miR-10b secretion. }\end{array}$ & {$[59,60]$} \\
\hline & $\operatorname{miR}-1246(\uparrow)$ & $\begin{array}{c}\text { Cancer cell } \\
\text { (MDA-MB-231, MCF-7) }\end{array}$ & $\begin{array}{c}\text { Epithelial cells } \\
\text { (MCF-10A, HMLE) }\end{array}$ & $\begin{array}{l}\text { CCNG2 (tightly } \\
\text { regulated through } \\
\text { the cell cycle) }\end{array}$ & $\begin{array}{l}\text { Cell proliferation; } \\
\text { invasion; drug } \\
\text { resistance }\end{array}$ & $\begin{array}{l}\text { Exosomal miR-1246 functions } \\
\text { in regulating breast tumor } \\
\text { progression and has the } \\
\text { potential for applications in } \\
\text { miRNA-based therapeutics. }\end{array}$ & {$[61]$} \\
\hline & $\operatorname{miR}-221 / 222(\uparrow)$ & $\begin{array}{l}\text { Cancer cell } \\
\text { [MCF-7/Tam] }\end{array}$ & $\begin{array}{l}\text { Cancer cell } \\
{[\text { MCF-7/WT }} \\
\text { (tamoxifen } \\
\text { sensitive)] }\end{array}$ & $\begin{array}{l}\text { ER } \alpha, \text { p27 (cell } \\
\text { cycle arrest, } \\
\text { autophagy, and } \\
\text { angiogenesis) }\end{array}$ & $\begin{array}{l}\text { Drug resistance } \\
\text { (tamoxifen) }\end{array}$ & $\begin{array}{l}\text { EV-secreted miR-221/222 serves } \\
\text { as signaling molecules to } \\
\text { mediate the communication of } \\
\text { tamoxifen resistance. }\end{array}$ & [62] \\
\hline & $\operatorname{miR}-222(\uparrow)$ & Cancer cell (MCF-7/Adr) & $\begin{array}{c}\text { Cancer cell } \\
\text { (MCF-7/sensitive) }\end{array}$ & & $\begin{array}{l}\text { Drug resistance } \\
\text { (adriamycin) }\end{array}$ & $\begin{array}{l}\text { Exosomes are effective in } \\
\text { transmitting drug resistance } \\
\text { and the delivery of miR-222 via } \\
\text { exosomes may be a mechanism. }\end{array}$ & {$[63]$} \\
\hline
\end{tabular}


Table 2. Cont.

\begin{tabular}{|c|c|c|c|c|c|c|c|}
\hline Stimulant & Cargo-microRNAs & Donor Cells & Recipient Cells & Gene Targets & $\begin{array}{l}\text { Biological } \\
\text { Activities }\end{array}$ & Major Findings & Refs \\
\hline & $\begin{array}{c}\operatorname{miR}-23 a, 29 a, 1246, \\
222,452(\uparrow)\end{array}$ & Cancer cell (MCF-7/Doc) & $\begin{array}{c}\text { Cancer cell } \\
\text { (MCF-7/sensitive) }\end{array}$ & $\begin{array}{l}\text { Sprouty2 [regulate } \\
\text { invasion and } \\
\text { metastasis] } \\
\text { (miR-23a), PTEN } \\
\text { (miR-222), APC4 } \\
\text { (miR-452) }\end{array}$ & $\begin{array}{l}\text { Drug resistance } \\
\text { (docetaxel) }\end{array}$ & $\begin{array}{c}\text { Abundant miRNAs of Doc/exo } \\
\text { in pathways implicated in } \\
\text { therapy failure. }\end{array}$ & [64] \\
\hline & $\begin{array}{l}\operatorname{miR}-100,222 \\
\text { 30a }(\uparrow)\end{array}$ & $\begin{array}{c}\text { Cancer cell (MCF-7/Doc, } \\
\text { MCF-7/Adr) }\end{array}$ & $\begin{array}{c}\text { Cancer cell } \\
\text { (MCF-7/sensitive) }\end{array}$ & PTEN (miR-222) & $\begin{array}{l}\text { Drug resistance } \\
\text { (docetaxel, } \\
\text { adriamycin) }\end{array}$ & $\begin{array}{l}\text { The involvement of miRNAs in } \\
\text { pathways implicated in cancer } \\
\text { pathogenesis, membrane } \\
\text { vesiculation, and } \\
\text { therapy failure. }\end{array}$ & [65] \\
\hline & $\begin{array}{l}\operatorname{miR}-23 a, 24,149, \\
222(\uparrow)\end{array}$ & Cancer cell (MCF-7/Adr) & $\begin{array}{c}\text { Cancer cell } \\
\text { (MCF-7/sensitive) }\end{array}$ & $\begin{array}{c}\text { Sprouty2 } \\
\text { (miR-23a), PTEN } \\
\text { p27 (miR-24) } \\
(\mathrm{miR}-222)\end{array}$ & $\begin{array}{l}\text { Drug resistance } \\
\text { (adriamycin) }\end{array}$ & $\begin{array}{l}\text { Adr/exo loaded miRNAs for its } \\
\text { production, release and which } \\
\text { were associated with Wnt } \\
\text { signaling pathway. Adr/exo } \\
\text { was able to increase the overall } \\
\text { resistance and regulate } \\
\text { gene levels. }\end{array}$ & [66] \\
\hline & miR-9, miR-155 ( $\uparrow)$ & $\begin{array}{c}\text { Cancer cell } \\
\text { (MDA-MB-231) }\end{array}$ & $\begin{array}{l}\text { Cancer cells } \\
\text { (MCF-7) }\end{array}$ & $\begin{array}{c}\text { PTEN (miR-9), } \\
\text { DUSP14 (miR-155) }\end{array}$ & Tumor growth & $\begin{array}{l}\text { Exosomal miRNAs can transfer } \\
\text { from highly metastatic cancer } \\
\text { cells to other low metastatic } \\
\text { cancer cells and can suppress } \\
\text { target genes in the } \\
\text { recipient cells. }\end{array}$ & {$[67,68]$} \\
\hline & $\operatorname{miR}-182(\uparrow)$ & $\begin{array}{l}\text { Cancer cell (miR-182 } \\
\text { transfected } \\
\text { MDA-MB-231) }\end{array}$ & $\begin{array}{l}\text { Cancer cell (naïve } \\
\text { MDA-MB-231 } \\
\text { cells) }\end{array}$ & & Tumorigenesis & $\begin{array}{l}\text { MiR-182 is packaged in } \\
\text { exosomes, detectable in } \\
\text { exosomes from cell culture } \\
\text { supernatant and human serum, } \\
\text { which may be transferred } \\
\text { between cells via a } \\
\text { microvesicle-dependent } \\
\text { mechanism. }\end{array}$ & [69] \\
\hline
\end{tabular}


Table 2. Cont.

\begin{tabular}{|c|c|c|c|c|c|c|c|}
\hline Stimulant & Cargo-microRNAs & Donor Cells & Recipient Cells & Gene Targets & $\begin{array}{l}\text { Biological } \\
\text { Activities }\end{array}$ & Major Findings & Refs \\
\hline & $\operatorname{miR}-134(\downarrow)$ & $\begin{array}{c}\text { Cancer cell } \\
\text { (miR-134-transfected } \\
\text { Hs578T, a TNBC cell } \\
\text { line; isogenic } \\
\text { sub-clone cells) }\end{array}$ & $\begin{array}{l}\text { Cancer cells } \\
\text { (Hs578Ts }(\mathrm{i}) 8 \\
\text { parent cells) }\end{array}$ & $\begin{array}{c}\text { STAT5B (control } \\
\text { Hsp90) }\end{array}$ & $\begin{array}{l}\text { Cellular } \\
\text { proliferation; } \\
\text { migration and } \\
\text { invasion; drug } \\
\text { resistance } \\
\text { (cisplatin, } \\
\text { anti-Hsp90 drug) }\end{array}$ & $\begin{array}{l}\text { (1) The direct transfection or EV } \\
\text { delivery transport route of } \\
\text { miRNA achieved different } \\
\text { effects. (2) MiR-134 had clinical } \\
\text { relevance in breast tumors. }\end{array}$ & [70] \\
\hline & $\operatorname{miR}-105(\uparrow)$ & $\begin{array}{c}\text { Cancer cell } \\
\text { (MDA-MB-231, } \\
\text { MCF-10A as the } \\
\text { control group) }\end{array}$ & $\begin{array}{l}\text { Endothelial cells } \\
\text { (HMVECs) }\end{array}$ & $\begin{array}{l}\text { ZO-1 (also called } \\
\text { tight junctions } \\
\text { protein } 1 \\
\text { migration-related } \\
\text { gene) }\end{array}$ & Metastasis & $\begin{array}{l}\text { Exosome-mediated transfer of } \\
\text { cancer cell-secreted miR-105 } \\
\text { efficiently destroys tight } \\
\text { junctions and the integrity of } \\
\text { these natural barriers against } \\
\text { metastasis. }\end{array}$ & [71] \\
\hline & $\operatorname{miR}-939(\uparrow)$ & $\begin{array}{c}\text { Cancer cell } \\
\text { (MDA-MB-231-GFP } \\
\text { cells) }\end{array}$ & $\begin{array}{l}\text { Endothelial cells } \\
\text { (HUVECs) }\end{array}$ & $\begin{array}{l}\text { VE-cadherin (a } \\
\text { component of } \\
\text { adherens junction } \\
\text { involved in vessel } \\
\text { permeability) }\end{array}$ & $\begin{array}{l}\text { Migration and } \\
\text { invasion }\end{array}$ & $\begin{array}{l}\text { MiR-939 could (1) increase } \\
\text { HUVECs monolayer } \\
\text { permeability; (2) favor } \\
\text { trans-endothelial migration by } \\
\text { the disruption of the } \\
\text { endothelial barrier. }\end{array}$ & [72] \\
\hline $\begin{array}{c}\text { MYC } \\
\text { (oncogene) }\end{array}$ & miR-105 ( $\uparrow)$ & $\begin{array}{l}\text { Cancer cell } \\
\text { (MDA-MB-231, } \\
\text { MCF-10A as the } \\
\text { control group) }\end{array}$ & $\begin{array}{c}\text { CAFs } \\
\text { (patient-derived } \\
\text { primary fibroblasts } \\
\text { CAF265922; fetal } \\
\text { lung fibroblast cell } \\
\text { line WI-38; mouse } \\
\text { embryonic } \\
\text { fibroblast cell line } \\
\text { NIH3T3) }\end{array}$ & MXI1 & Tumor growth & $\begin{array}{l}\text { Reprogrammed CAFs would } \\
\text { ultimately promote tumor } \\
\text { growth by leading different } \\
\text { metabolic pathways under the } \\
\text { circumstances of efficient or } \\
\text { insufficient nutrition. }\end{array}$ & [73] \\
\hline
\end{tabular}


Table 2. Cont.

\begin{tabular}{|c|c|c|c|c|c|c|c|}
\hline Stimulant & Cargo-microRNAs & Donor Cells & Recipient Cells & Gene Targets & $\begin{array}{l}\text { Biological } \\
\text { Activities }\end{array}$ & Major Findings & Refs \\
\hline & miR-122 ( $\uparrow)$ & $\begin{array}{c}\text { Cancer cell } \\
\text { (MDA-MB-361, } \\
\text { MDA-MB-468, } \\
\text { MDA-MB-231, } \\
\text { MDA-MB-231-HM, } \\
\text { SKBR3, BT4, MCF-10A } \\
\text { as the control group) }\end{array}$ & $\begin{array}{l}\text { Lung fibroblast, brain } \\
\text { astrocytes, neurons }\end{array}$ & PKM2, GLUT1 & $\begin{array}{l}\text { Reprogram } \\
\text { glucose } \\
\text { metabolism; } \\
\text { cancer cell } \\
\text { proliferation; } \\
\text { metastasis }\end{array}$ & $\begin{array}{l}\text { Exosomal miR-122 inhibited the } \\
\text { glucose uptake by niche cells } \\
\text { and increased glucose } \\
\text { availability to cancer cells, } \\
\text { while inhibition of miR-122 } \\
\text { decreases the incidence of } \\
\text { metastasis in vivo. }\end{array}$ & [74] \\
\hline & miR-940 ( $\uparrow)$ & $\begin{array}{c}\text { Cancer cell } \\
\text { (MDA-MB-231) }\end{array}$ & $\begin{array}{l}\text { Human mesenchymal } \\
\text { stem cells (MSC, } \\
\text { UCB408E6E7TERT-33) }\end{array}$ & $\begin{array}{l}\text { ARHGAP1, } \\
\text { FAM134A }\end{array}$ & Bone metastasis & $\begin{array}{l}\text { miR-940 facilitates the } \\
\text { osteogenic differentiation of } \\
\text { human MSCs. }\end{array}$ & [75] \\
\hline & $\operatorname{miR}-770(\downarrow)$ & $\begin{array}{c}\text { Cancer cell } \\
\text { (MDA-MB-231, } \\
\text { MDA-MB-468) }\end{array}$ & TAMs (THP-1 cell) & STMN1 & $\begin{array}{l}\text { Drug resistance } \\
\text { (doxorubicin); } \\
\text { metastasis }\end{array}$ & $\begin{array}{l}\text { miR-770 could (i) influence the } \\
\text { polarization of macrophages } \\
\text { which promote M1 phenotype } \\
\text { and inhibit M2 phenotype, (ii) } \\
\text { suppress the } \\
\text { doxorubicin-resistance and } \\
\text { metastasis of TNBC cells }\end{array}$ & {$[76]$} \\
\hline HIF- $1 \alpha$ & $\operatorname{miR}-210(\uparrow)$ & $\begin{array}{c}\text { Cancer cell } \\
\text { (MDA-MB-231, 4T1) }\end{array}$ & $\begin{array}{c}\text { Endothelial cells } \\
\text { (SVEC), macrophages } \\
\text { (Raw264.7), stem cells } \\
\text { (MBs-MSC), } \\
\text { fibroblasts (3T3), and } \\
\text { dendritic cells } \\
\text { (JAWS2). }\end{array}$ & $\begin{array}{l}\text { Ephrin A3, PTP1B } \\
\text { (vascular } \\
\text { remodeling } \\
\text { related genes) }\end{array}$ & Angiogenesis & $\begin{array}{l}\text { A miR-210 specific reporter } \\
\text { system to realize in vitro and } \\
\text { in vivo visualization. }\end{array}$ & [78] \\
\hline \multirow[t]{2}{*}{ HIF- $1 \alpha$} & $\operatorname{miR}-210(\uparrow)$ & $\begin{array}{c}\text { Cancer cell } \\
\text { (MDA-MB-231, } \\
\text { SKBR3, MCF-7) }\end{array}$ & TME & & & $\begin{array}{l}\text { Hypoxic cancer cells may } \\
\text { release more exosomes into } \\
\text { their microenvironment to } \\
\text { promote their own survival } \\
\text { and invasion }\end{array}$ & [79] \\
\hline & $\operatorname{miR}-9(\uparrow)$ & $\begin{array}{l}\text { Cancer cell } \\
\text { (MDA-MB-231, } \\
\text { MDA-MB-468) }\end{array}$ & $\begin{array}{l}\text { Normal fibroblasts } \\
\text { (isolated from } \\
\text { specimens belonging } \\
\text { to patients) }\end{array}$ & $\begin{array}{l}\text { mainly involved in } \\
\text { cell motility and } \\
\text { ECM remodeling } \\
\text { pathways }\end{array}$ & $\begin{array}{l}\text { Tumor growth; } \\
\text { migration and } \\
\text { invasion }\end{array}$ & $\begin{array}{c}\text { (1) Enhance cell motility; (2) } \\
\text { enhance the switch to CAF } \\
\text { phenotype }\end{array}$ & {$[80]$} \\
\hline
\end{tabular}


2.2. Exosomes from Stromal Cells Can Transfer miRNAs to Cancer Cells and Contribute to Cancer Progression (Table 3)

In turn, as the reports accumulated, stromal cells can also express exosomes to function in cancer cells (Figure 2). For instance, miR-9 can be secreted in exosomes by both breast cancer cells and CAFs [80]. When miR-9 is transferred from tumor cells, it can enhance the transformation of normal fibroblasts (NFs) to CAFs and its migration and invasion abilities. Conversely, CAFs can secrete miR-9 to tumor cells and NFs to promote tumor growth [80]. Dioufa et al. [81] observed that the tumor-derived exosomes helped to transfer the tumor cells to the liver and then remain in the dormancy state in the early stage of metastasis, which was characterized in slow proliferation, insensitivity to chemotherapy and difficulty in discovery, resulting in recurrence and poor prognosis [82]. However, exosomes from hepatic niche cells led to an increased mesenchymal to epithelial reverting transition (MErT) of cancer cells, which was explained as the adaptation process of tumor cells in heterogeneous organs [81]. Uen et al. [83] demonstrated that miR-122-5p, which was found in the human hepatoma cells' exosomes, would target at syndecan-1 (SDC-1) and promote breast cancer cell mobility.

A relatively higher level of miR-155 was detected in exosomes of breast cancer stem cells (CSC) and chemo-resistant cancer cells. When sensitive cancer cells were co-cultured with resistant cells' exosomes, the migration ability and chemoresistance was promoted [84]. Exosomal miR-23b was reported to transit from bone marrow mesenchymal stem cells (BM-MSCs) to metastatic breast cancer cells which were homing to bone marrow (BM2), and the BM2 cells could be induced to enter into dormancy by inhibiting myristoylated alanine-rich C kinase substrate (MARCKS) [82]. Similarly, miR-222/223 [85], miR-127 and miR-197 [86], miR-21 and miR-34a [87], miR-126a [88] in exosomes from BM-derived cells also supported tumor growth in different ways such as drug resistance, dormancy, metastasis, and angiogenesis (Table 3).

Interestingly, CAFs could secrete exosomes encapsulating with miR-221/222 [89], miR-21, -378e, -143 [90] to enhance the development of cancer cells to a more aggressive phenotype with increased stemness, EMT ability, etc. Additionally, exosomes from interleukin-4 (IL-4) activated TAMs, upregulated the expression of miR-223 in breast cancer cells with co-culture systems, which further promoted the invasiveness of cancer cells by disrupting the Mef2c- $\beta$-catenin pathway [91].

However, there are some reports that exosomal anti-cancer miRNAs would also be secreted by stromal cells to fight with the malignancies (Table 3). MSC-derived exosomes shuttled miR-16 [92] and miR-100 (inhibiting the mTOR/HIF-1 $\alpha /$ VEGF pathway) [93] to the nearby cancer cells and decreased their VEGF expression, subsequently resulting in inhibition of the endothelial cells' vascular behavior. After chemotherapy, the upregulation of miR-503 via exosomes in endothelial cells reduced cancer cells' proliferation and invasion through targeting cyclin D2 (CCDN2) and CCDN3 [94]. 
Table 3. Evidence supporting a role for exosomal microRNAs in cancer cell-cell communication (from stromal cells).

\begin{tabular}{|c|c|c|c|c|c|c|c|}
\hline Stimulant & Cargo-microRNAs & Donor Cells & Recipient Cells & Gene Targets & $\begin{array}{l}\text { Biological } \\
\text { Activities }\end{array}$ & Major Findings & Refs \\
\hline & $\operatorname{miR}-9(\uparrow)$ & CAFs & $\begin{array}{l}\text { Cancer cell } \\
\text { (MDA-MB-231, } \\
\text { MDA-MB-468); } \\
\text { Normal } \\
\text { Fibroblasts }\end{array}$ & E-cadherin & $\begin{array}{l}\text { Migration, invasion, } \\
\text { cell proliferation }\end{array}$ & $\begin{array}{l}\text { MiR-9 was an important player } \\
\text { in the crosstalk between cancer } \\
\text { cells and stroma. }\end{array}$ & [80] \\
\hline & $\begin{array}{l}\operatorname{miR}-186,23 a, \\
-205(\uparrow)\end{array}$ & $\begin{array}{l}\text { The hepatic niche } \\
\text { (HepN) }\end{array}$ & $\begin{array}{c}\text { Cancer cell } \\
\text { (MDA-MB-231) }\end{array}$ & $\begin{array}{l}\text { Regulate } \\
\text { E-cadherin } \\
\text { transcription and } \\
\text { MErT induction }\end{array}$ & MErT & $\begin{array}{l}\text { The normal tissue/HepN } \\
\text { derived exosomes in enabling } \\
\text { seeding and entry into the } \\
\text { dormancy of the cancer cells at } \\
\text { the metastatic site. }\end{array}$ & [81] \\
\hline & $\operatorname{miR}-23 b(\uparrow)$ & $\begin{array}{l}\text { Bone marrow } \\
\text { mesenchymal stem } \\
\text { cells (BM-MSC) }\end{array}$ & $\begin{array}{l}\text { Cancer cell (BM2 } \\
\text { cell, } \\
\text { MDA-MB-231) }\end{array}$ & $\begin{array}{l}\text { MARCKS (encode } \\
\text { a protein that } \\
\text { promotes cell } \\
\text { cycling and } \\
\text { motility) }\end{array}$ & $\begin{array}{l}\text { Dormancy; drug } \\
\text { resistance } \\
\text { (docetaxel) }\end{array}$ & $\begin{array}{l}\text { (1) They generated a bone } \\
\text { marrow-metastatic human } \\
\text { breast cancer cell line (BM2); } \\
\text { (2) Exosomal transfer of } \\
\text { miRNAs from the bone marrow } \\
\text { may promote breast cancer cell } \\
\text { dormancy in a metastatic niche. }\end{array}$ & [82] \\
\hline & miR-122-5p ( $\uparrow)$ & $\begin{array}{l}\text { Human hepatoma } \\
\text { cells (Huh-7, Hep3B) }\end{array}$ & $\begin{array}{l}\text { Cancer cells } \\
\text { (MCF-7) }\end{array}$ & syndecan-1 (SDC1) & Metastasis & $\begin{array}{l}\text { Metastasis or mobility of breast } \\
\text { cancer cells might be affected by } \\
\text { circulating miR-122-5p and not } \\
\text { directly correlated with the } \\
\text { progression of breast cancer. }\end{array}$ & [83] \\
\hline & $\operatorname{miR}-155(\uparrow)$ & $\begin{array}{l}\text { Breast CSC; } \\
\text { DOX-/PTX-resistant } \\
\text { MCF-7 cell line }\end{array}$ & $\begin{array}{c}\text { Cancer cell } \\
\text { (MCF-7 cell, } \\
\text { MDA-MB-231) }\end{array}$ & $\begin{array}{c}\text { TGF- } \beta, \text { C/EBP- } \beta \\
\text { and FOXO3a }\end{array}$ & $\begin{array}{l}\text { EMT; migration; } \\
\text { chemoresistance }\end{array}$ & $\begin{array}{l}\text { Exosomes may intermediate } \\
\text { resistance, and migration } \\
\text { capacity to sensitive cells partly } \\
\text { through exosome transfer } \\
\text { of miR-155. }\end{array}$ & [84] \\
\hline
\end{tabular}


Table 3. Cont

\begin{tabular}{|c|c|c|c|c|c|c|c|}
\hline Stimulant & Cargo-microRNAs & Donor Cells & Recipient Cells & Gene Targets & $\begin{array}{l}\text { Biological } \\
\text { Activities }\end{array}$ & Major Findings & Refs \\
\hline & $\operatorname{miR}-222 / 223(\uparrow)$ & $\begin{array}{c}\text { MSC (naive MSC; } \\
\text { T47D, } \\
\text { MDA-MB-231-primed } \\
\text { MSCs) }\end{array}$ & $\begin{array}{c}\text { Cancer cell } \\
\text { (MDA-MB-231, } \\
\text { T47D) }\end{array}$ & & $\begin{array}{l}\text { Cycle quiescence; } \\
\text { dormancy; drug } \\
\text { resistance } \\
\text { (carboplatin) }\end{array}$ & $\begin{array}{c}\text { Breast cancer cells prime MSC } \\
\text { to release exosomal } \\
\text { miR-222/223, which in turn } \\
\text { promotes quiescence in a subset } \\
\text { of cancer cells and confers } \\
\text { drug resistance. }\end{array}$ & [85] \\
\hline & $\begin{array}{c}\operatorname{miR}-127,197,222 \\
223(\uparrow)\end{array}$ & $\begin{array}{l}\text { BM stromal cells } \\
\text { (prepared from BM } \\
\text { aspirates of } \\
\text { healthy donors) }\end{array}$ & $\begin{array}{c}\text { Cancer cell } \\
\text { (MDA-MB-231, } \\
\text { T47D) }\end{array}$ & $\begin{array}{l}\text { CXCL12 } \\
\text { (chemokine } \\
\text { family) }\end{array}$ & $\begin{array}{c}\text { Cycle quiescence; } \\
\text { dormancy }\end{array}$ & $\begin{array}{l}\text { (1) The transfer of miRNAs } \\
\text { from BM stroma to BC cells } \\
\text { might play a role in the } \\
\text { dormancy of BM metastases. } \\
\text { (2) Gap-junction maybe another } \\
\text { way of the transfer of miRNAs. }\end{array}$ & [86] \\
\hline & miR-21, 34a ( $\uparrow)$ & Human MSC & $\begin{array}{c}\text { Cancer cell } \\
\text { (MCF-7, } \\
\text { osteosarcoma cell) }\end{array}$ & & Cell proliferation & $\begin{array}{l}\text { First comprehensive-omics } \\
\text { based study that characterized } \\
\text { the complex cargo of } \\
\text { extracellular vesicles secreted } \\
\text { by hMSCs and their role in } \\
\text { supporting breast cancers. }\end{array}$ & [87] \\
\hline \multirow[t]{2}{*}{ IL-13 } & $\operatorname{miR}-126 \mathrm{a}(\uparrow)$ & MDSC & $\begin{array}{l}\text { Cancer cell (4T1, } \\
\text { MDA-MB-231); } \\
\text { IL-13+Th2 cell }\end{array}$ & S100A9 & $\begin{array}{l}\text { Lung metastasis; } \\
\text { angiogenesis }\end{array}$ & $\begin{array}{c}\text { Doxorubicin treatment led to an } \\
\text { enhancement of IL-33 in breast } \\
\text { cancer cells, IL-13 receptor and } \\
\text { miR-126a in MDSCs in a } \\
\text { positive feedback loop manner. }\end{array}$ & [88] \\
\hline & $\operatorname{miR}-221 / 222(\uparrow)$ & CAFs & $\begin{array}{l}\text { Cancer cell (MCF-7 } \\
\text { cell line long-term } \\
\text { conditioned for } \\
\text { growth in estrogen } \\
\text { depleted } \\
\text { conditions) }\end{array}$ & $\begin{array}{l}\text { ER (estrogen } \\
\text { receptor) }\end{array}$ & $\begin{array}{l}\text { ER-negative } \\
\text { phenotype }\end{array}$ & $\begin{array}{l}\text { CAF-secreted microRNAs are } \\
\text { directly involved in } \\
\text { ER-repression and may } \\
\text { contribute to the } \\
\text { MAPK-induced ER-repression } \\
\text { in breast cancer cells. }\end{array}$ & [89] \\
\hline
\end{tabular}


Table 3. Cont.

\begin{tabular}{|c|c|c|c|c|c|c|c|}
\hline Stimulant & Cargo-microRNAs & Donor Cells & Recipient Cells & Gene Targets & $\begin{array}{l}\text { Biological } \\
\text { Activities }\end{array}$ & Major Findings & Refs \\
\hline & $\begin{array}{c}\operatorname{miR}-21,-378 \mathrm{e} \\
-143(\uparrow)\end{array}$ & $\begin{array}{c}\text { CAFs; Normal } \\
\text { fibroblasts with } \\
\text { overexpressed miRs }\end{array}$ & $\begin{array}{c}\text { Cancer cell (BT549, } \\
\text { MDA-MB-231, } \\
\text { T47D) }\end{array}$ & & $\begin{array}{l}\text { Cell growth; } \\
\text { stemness; EMT }\end{array}$ & $\begin{array}{l}\text { CAFs strongly promote the } \\
\text { development of an aggressive } \\
\text { breast cancer cell phenotype. }\end{array}$ & [90] \\
\hline \multirow[t]{4}{*}{ IL-4 } & $\operatorname{miR}-223(\uparrow)$ & $\begin{array}{l}\text { TAMs (isolated from } \\
\text { the peripheral blood } \\
\text { and activated by } \\
\text { adding IL-4) }\end{array}$ & $\begin{array}{c}\text { Cancer cell } \\
\text { (SKBR3, } \\
\text { MDA-MB-231) }\end{array}$ & $\begin{array}{l}\text { Mef2c (inhibit } \\
\text { proliferation and } \\
\text { granulocyte } \\
\text { function) }\end{array}$ & Invasion & $\begin{array}{l}\text { MiR-223 may target at the } \\
\text { Mef2c- } \beta \text {-catenin pathway to } \\
\text { mediate breast cancer } \\
\text { cell invasion. }\end{array}$ & [91] \\
\hline & $\operatorname{miR}-16(\uparrow)$ & MSC & $\begin{array}{l}\text { Cancer cell (4T1); } \\
\text { Mouse endothelial } \\
\text { cell line (SVEC) }\end{array}$ & VEGF & Angiogenesis & $\begin{array}{l}\text { MiR-16 was partially } \\
\text { responsible for the } \\
\text { antiangiogenic effect of } \\
\text { MSC-derived exosomes. }\end{array}$ & [92] \\
\hline & $\operatorname{miR}-100(\uparrow)$ & MSC & $\begin{array}{c}\text { Cancer cell } \\
\text { (MDA-MB-231, } \\
\text { MCF-7, T47D); } \\
\text { Endothelial cells } \\
\text { (HUVECs) }\end{array}$ & mTOR & Angiogenesis & $\begin{array}{l}\text { MSC-derived exosomes induce } \\
\text { a decrease in the expression and } \\
\text { secretion of VEGF through } \\
\text { modulating the mTOR/HIF-1 } \alpha \\
\text { signaling axis in breast } \\
\text { cancer-derived cells. }\end{array}$ & [93] \\
\hline & $\operatorname{miR}-503(\uparrow)$ & $\begin{array}{l}\text { Endothelial cells } \\
\text { (HUVECs) }\end{array}$ & $\begin{array}{l}\text { Cancer cell (A549, } \\
\text { HCT116, } \\
\text { MDA-MB-231, } \\
\text { U87) }\end{array}$ & CCND2, CCND3 & $\begin{array}{l}\text { Cell proliferation; } \\
\text { invasion }\end{array}$ & $\begin{array}{l}\text { Increased plasmatic miR-503 in } \\
\text { breast cancer patients after } \\
\text { neoadjuvant chemotherapy, } \\
\text { which could be partly due to } \\
\text { increased miRNA secretion }\end{array}$ & [94] \\
\hline
\end{tabular}




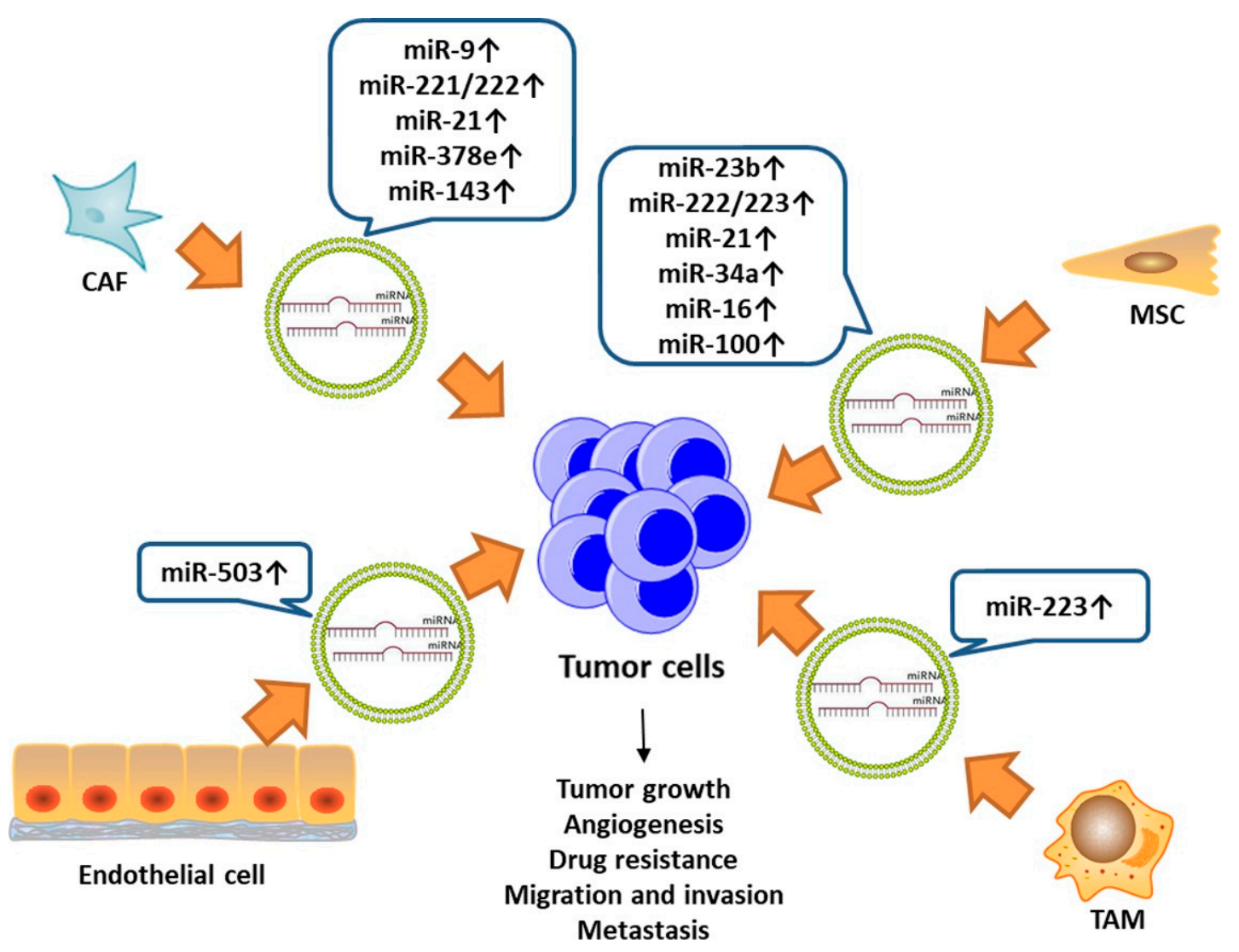

Figure 2. Exosomal microRNAs from stromal cells could enter and function in cancer cells and contribute to cancer progression including tumor growth, angiogenesis, metastasis, etc.

\subsection{Circulating MicroRNAs in Exosomes Imply Their Potential Biomarker Value}

Some circulating microRNAs contained in exosomes can potentially be regarded as predictive, diagnostic and prognostic biomarkers for breast cancer (Table 4). The advantages of exo-miRs over miRs are obvious: (1) Exo-miRs act as cell-cell communicator and circulate in the body fluids, such as peripheral blood andbreast milk. Thus, the collection method is non-invasive, or simply a common method like blood collection. When it comes to miRs, it is not easy to get tumor tissues and pathological diagnosis is still the gold standard. (2) It has also been reported that the expression level of some special exo-miRs have shown significant differences in early stages of cancer, even during dormancy period. In this case, miRs in tumor tissues cannot be detected. (3) Post-operative monitoring is even more important because recurrence and metastasis are still the greatest cause of breast cancer death. Additionally, exo-miRs can be easily detected and constantly monitored. 
Table 4. Preclinical evaluation of exosomal cargo as cancer biomarkers.

\begin{tabular}{|c|c|c|c|c|c|}
\hline Cargo & Patient Cohorts & $\begin{array}{l}\text { Exosome Source } \\
\text { (Isolation Method) }\end{array}$ & Assay Used & Outcome and Utility & Refs \\
\hline $\begin{array}{c}\text { miR-106a-3p, 106a-5p, } \\
\text { 20b-5p, 92a-2-5p (plasma } \\
\text { miRNAs); miR-106a-5p, } \\
\text { 19b-3p, 20b-5p, 92a-3p } \\
\text { (serum miRNAs) }\end{array}$ & $\begin{array}{l}400 \text { plasma samples (from } 200 \\
\text { BC patients and } 200 \text { healthy } \\
\text { controls (HCs)), } 406 \text { serum } \\
\text { samples (from } 204 \mathrm{BC} \text { patients } \\
\text { and } 202 \mathrm{HCs} \text { ), }\end{array}$ & $\begin{array}{l}\text { plasma (from } 32 \mathrm{BC} \\
\text { patients and } 32 \mathrm{HCs} \text { ), } \\
\text { serum (from } 32 \mathrm{BC} \\
\text { patients and } 32 \mathrm{HCs} \text { ) }\end{array}$ & qRT-PCR & $\begin{array}{l}\text { Except for the expression of } \\
\text { miR-20b-5p, the expression patterns } \\
\text { of exosomal miRNAs were } \\
\text { concordant between plasma and } \\
\text { serum, indicating the potential use of } \\
\text { exosomal miRNAs as biomarkers. }\end{array}$ & [95] \\
\hline $\operatorname{miR}-21,1246(\uparrow)$ & $\begin{array}{l}\text { exosomes from the conditioned } \\
\text { media of human breast cancer } \\
\text { cell lines, mouse plasma of } \\
\text { patient-derived orthotopic } \\
\text { xenograft models (PDX), and } \\
\text { human plasma samples from } \\
16 \text { patients }\end{array}$ & $\begin{array}{l}\text { plasma } \\
\text { (ultracentrifugation, } \\
\text { ExoQuick) }\end{array}$ & $\begin{array}{l}\text { next-generation small } \\
\text { RNA sequencing; } \\
\text { qRT-PCR }\end{array}$ & $\begin{array}{l}\text { The combination of plasma exosome } \\
\text { miR-1246 and miR- } 21 \text { is a better } \\
\text { indicator of breast cancer than their } \\
\text { individual levels. }\end{array}$ & [96] \\
\hline $\operatorname{miR}-373(\uparrow)$ & $\begin{array}{c}168 \text { patients with invasive } \\
\text { breast cancer, } 19 \text { patients with } \\
\text { benign breast diseases and } 28 \\
\text { healthy women }\end{array}$ & serum (ExoQuick) & RT-PCR & $\begin{array}{l}\text { Serum levels of exosomal miR-373 } \\
\text { are linked to triple-negative and } \\
\text { more aggressive breast carcinomas. }\end{array}$ & [97] \\
\hline $\operatorname{miR}-155(\uparrow)$ & $\begin{array}{l}259 \text { participants, including } \\
\text { patients with breast cancer or } \\
\text { benign breast tumors, members } \\
\text { of breast cancer families, and } \\
\text { matched healthy } \\
\text { female controls. }\end{array}$ & $\begin{array}{c}\text { plasma } \\
\text { (ultracentrifugation) }\end{array}$ & nest-qPCR & $\begin{array}{c}\text { For patients with early stage or } \\
\text { localized breast cancer, there were } \\
\text { high levels of miR-155 in both plasma } \\
\text { and blood cells. }\end{array}$ & [98] \\
\hline miR-130a-3p ( $\downarrow)$ & $\begin{array}{l}40 \text { pairs of breast cancer and } \\
\text { adjacent normal tissues, } 40 \\
\text { pairs of blood samples from } \\
\text { patients with breast cancer and } \\
\text { healthy controls (confirmed as } \\
\text { invasive ductal breast cancer, } \\
\text { and no patient had received any } \\
\text { chemotherapy or radiotherapy } \\
\text { ahead of surgery.) }\end{array}$ & $\begin{array}{l}\text { circulating blood } \\
\text { (ExoQuick Exosomal } \\
\text { Extraction Kit) }\end{array}$ & & $\begin{array}{l}\text { Lower levels of exosome-derived } \\
\text { miR-130a-3p are associated with } \\
\text { lymph node metastasis }(p=0.0019) \\
\text { and advanced TNM stage } \\
(p=0.0014)\end{array}$ & [99] \\
\hline
\end{tabular}


Table 4. Cont.

\begin{tabular}{|c|c|c|c|c|c|}
\hline Cargo & Patient Cohorts & $\begin{array}{l}\text { Exosome Source } \\
\text { (Isolation Method) }\end{array}$ & Assay Used & Outcome and Utility & Refs \\
\hline miR-16 ( $), 30 \mathrm{~b}(\downarrow), 93(\uparrow)$ & $\begin{array}{c}111 \mathrm{BC} \text { patients, } 42 \text { DCIS } \\
\text { patients and } 39 \text { healthy women }\end{array}$ & plasma & TaqMan real-time PCR & $\begin{array}{l}\text { (1) The levels of exosomal miR-16 were } \\
\text { higher in plasma of BC }(p=0.034) \text { and } \\
\text { DCIS ( } p=0.047) \text { patients than healthy } \\
\text { women and were associated with } \\
\text { estrogen }(p=0.004) \text { and progesterone } \\
(p=0.008) \text { receptor status. ( } 2 \text { In } \\
\text { estrogen-positive patients miR-16 was } \\
\text { significantly enriched in exosomes } \\
(p=0.0001) \text {. ( } 3 \text { ) Lower levels of exosomal } \\
\text { miR-30b were associated with recurrence } \\
(p=0.034) .(4) \text { Exosomal miR-93 was } \\
\text { upregulated in DCIS patients }(p=0.001) \text {. }\end{array}$ & [100] \\
\hline $\operatorname{miR}-200 \mathrm{c}(\uparrow),-141(\uparrow)$ & $\begin{array}{l}259 \text { human subjects, including } \\
114 \text { patients with breast cancer, } \\
30 \text { patients with benign breast } \\
\text { tumors, } 21 \text { women with a } \\
\text { family history of breast cancer, } \\
\text { and } 94 \text { healthy women }\end{array}$ & $\begin{array}{c}\text { plasma } \\
\text { (ultracentrifugation) }\end{array}$ & nest-qPCR & $\begin{array}{l}\text { Circulating levels of miR-200c and } \\
\text { miR-141 are potential biomarkers for } \\
\text { early detection of breast } \\
\text { cancer metastases. }\end{array}$ & [101] \\
\hline miR-223-3p ( $)$ & $\begin{array}{l}185 \text { breast cancer patients, } \\
20 \text { healthy volunteers }\end{array}$ & $\begin{array}{c}\text { plasma } \\
\text { (ultracentrifugation) }\end{array}$ & $\begin{array}{l}\text { microRNA (miRNA) } \\
\text { microarray; RT-qPCR }\end{array}$ & $\begin{array}{l}\text { (1) identify the invasive lesions of DCIS } \\
\text { patients diagnosed by biopsy; ( } 2) \\
\text { significantly associated with the } \\
\text { malignancy of breast cancer. }\end{array}$ & [102] \\
\hline $\operatorname{miR}-21(\uparrow), 105(\uparrow), 155(\uparrow)$ & $\begin{array}{l}53 \text { breast cancer women ( } 6 \text { of } \\
\text { them were diagnosed as } \\
\text { metastatic patients) and } 8 \\
\text { healthy donors }\end{array}$ & serum & qPCR & $\begin{array}{l}\text { During neoadjuvant treatment, exosomal } \\
\text { miRNA-21 expression levels directly } \\
\text { correlated with tumor size }(p=0.039) \\
\text { and inversely with Ki67 expression } \\
\qquad(p=0.031)\end{array}$ & [103] \\
\hline $\begin{array}{l}\text { miR-340-5p ( }), 17-5 p(\downarrow) \\
\quad \text { 130a-3p }(\downarrow), 93-5 p(\downarrow)\end{array}$ & $\begin{array}{c}16 \text { patients with primary breast } \\
\text { cancer with recurrence and } 16 \\
\text { without recurrence; } 35 \text { breast } \\
\text { cancer patients with and } 39 \\
\text { without recurrence }\end{array}$ & serum (ExoQuick) & qRT-PCR & $\begin{array}{l}\text { There are different expression patterns of } \\
\text { miRNAs between tumor tissues } \\
\text { and serum }\end{array}$ & [104] \\
\hline
\end{tabular}


Plasma- and serum-derived miR-106a-5p and miR-20b-5p, belonging to miR-106a-363 cluster on chromosome $X$, showed an increasing trend in tissues and exosomes, indicating their role as potential diagnostic biomarkers [95]. In addition, a combination of multiple markers may also be a possible way to indicate the presence of breast cancer. For example, exosomal miR-12 and miR-1246 were proved to be a potential combined indicator [96]. Cell-free miR-101 and miR-373 in blood serum exhibited significant differences between malignant and benign tumors, and it is also worth noting that the higher content of exosomal miR-373 was associated with malignant breast cancer like TNBC [97]. Gao et al. [98] also reported that high level of miR-155, which may be derived from blood cells exosomes, was found in the early stage in cancer patients. Additionally, miR-130a-3p (tumor suppressor) [99], miR-16, miR-30b and miR-93 [100], miR-200c and miR-141 [101], and miR-223-3p [102] in exosomes also exhibited valuable functions to classify cancer stages (Table 4).

Recurrence often happens in breast cancer patients even after a mastectomy, which is totally different from patients never being treated, so the development of molecular markers for recurrence and treatment monitoring is very essential. High level of exosomal miR-21, -105, and miR-222 in serum samples [103] could possibly become a complementary tool for prognostic and monitoring use clinically because the level of miR-21 was proved to link with tumor size and Ki-67 expression during the treatment. The miRNA profile was detected in clinical patients with or without recurrence, and the level of miR-340-5p, miR-17-5p, miR-130a-3p, and miR-93-5p exhibited close relation with recurrence rate in their logistic regression analysis [104].

When the sample (e.g., plasma, serum) are obtained, the usual method is to use ultracentrifugation or commercial kits to extract and purify exosomes, and then use the transmission electron microscope (TEM) to detect their diameter size (30-100 nm), western blot (WB) to determine surface biomarkers (such as CD63, CD81, CD9), and other methods to confirm that the isolated EVs are exosomes, and to preserve in low temperature afterwards. When testing microRNAs, experimental methods such as RNA sequencing or qRT-PCR will be used. Exosomes uptake can be observed by PKH67 staining or confocal microscopy detection of fluorescence. Furthermore, since miRNAs can easily get degraded with time, different in situ and quantitative methods were also explored in order to detect the content of exosomal miRNAs in a faster and better manner. A direct method without RNA isolation or purification procedures, which was also evaluated in the terms of specificity, accuracy and efficiency, was used to prove miR-106a in plasma as a potential diagnosis biomarker [105]. Zhai et al. [106] synthesized an in situ probe which can quantitatively evaluate the level of miR-1246 in plasma exosomes with high degree of sensitivity and specificity, which is a promising translation for clinical use. Likewise, other reported methods for detecting exosomal miRNAs are mainly based on biosensors [107,108]; fluorescent probes [109,110]; DNA enzyme probes [111]; green fluorescent protein (GFP) tag technology [112]; weight-dependent molecular sieves [113], etc.

It is necessary to develop more effective, specific, sensitive biomarkers and detection methods to accelerate detection speed and improve patients' compliance. In the future, this kind of reagent will make it possible for a single drop of blood to verdict breast cancer, different from subtypes and treatment response monitoring.

\section{Therapeutic Method Targeting at the Exosomal microRNAs}

The important role of exosomal miRNAs in cancer progress cannot be ignored, so it is also significant (1) to develop new drugs targeting at vital miRNAs and (2) to achieve a novel treatment of the exosomes with therapeutic microRNAs. 
The mechanisms of some clinical anticancer drugs from natural herbs or synthetic sources are reported to be partly dependent on miRNAs as exosomal cargoes (Table 5). D Rhamnose $\beta$-hederin $(\mathrm{DR} \beta-\mathrm{H})$, a triterpenoid saponin, could reduce the growth and apoptosis of cancer cells by inhibiting the secretion process of exosomes. Subsequently, some specifically encapsulated miRNAs, including miR-130a and miR-425, were also downregulated [114]. Shikonin (SK) could also suppress exosome release accompanying with reduced miR-128 [115] and restrain the cancer-promoting effects of preadipocytes through disturbing miR-140/SOX9 signaling [116]. Epigallocatechin gallate (EGCG) is being pointed out to express anti-cancer activity by inhibiting the macrophages infiltration in TME through upregulating miR-16 in exosomes [117], and chemo-susceptibility could be elevated by $\beta$-elemene through affecting the expression of resistance-related genes such as miR-34a, miR-452, Pgp, and PTEN [118]. Hannafon et al. [119] reported that after docosahexaenoic acid (DHA) administration, exosomes secreted from breast cancer cells mediated the increase of miR-23b and miR-320b in recipient endothelial cells and decreased the expression of target genes and corresponding proteins (PLAU, AMOTL1, NRP1, ETS2, respectively), thus inhibiting their tube formation and angiogenesis capability.

Increasing evidence indicated that exosomes are important carriers and they probably can be manipulated to deliver tumor suppressor-miRNA or oncomiR-inhibitors to express their potential therapeutic effects (Table 5). As described, exosomal let-7a from donor cells was specifically delivered to epidermal growth factor receptor (EGFR)-expressing tumor sites for therapeutic use [120]. Recently, O'Brien et al. [121] genetically modified MSCs by lentiviral transduction to enrich miR-379 in derivative extracellular vesicle (EV), which showed significant anti-cancer activity in vivo by direct delivery. Meanwhile, tumor-derived exosomes could also be engineered to overexpress miR-155, -142, and let-7i by electroporation to mature dendritic cells and to trigger the immunity process [122], to load siRNAs or miRNAs by sonication to knockdown oncogene like HER2 [123]. Co-transfection of antagomiR-222/223 into MSCs reversed tumor dormancy and drug resistance [85]. Gold nanoparticle (AuNP)-based gene silencing technology could also load anti-gene/miRNA oligonucleotides [124], and locked nucleic acid (LNA)-modified BM-MSCs could secrete anti-miR-142-3p oligonucleotides in exosomes and exert inhibitory effects in vitro and in vivo [125]. 
Table 5. EVs as drug delivery agents for cancer therapy.

\begin{tabular}{|c|c|c|c|c|c|c|c|}
\hline $\begin{array}{l}\text { Therapeutic } \\
\text { Cargo }\end{array}$ & EV Source & Recipient Cells & Target Gene & $\begin{array}{c}\text { Drug Loading } \\
\text { Techniques/POSSIBLE } \\
\text { Drugs }\end{array}$ & Biological Activities & Key Findings & Refs \\
\hline antagomiR-222/223 & MSCs & $\begin{array}{c}\text { Cancer cell } \\
\text { (MDA-MB-231, } \\
\text { T47D) }\end{array}$ & & $\begin{array}{l}\text { Co-transfection } \\
\text { (Lipofectamine } \\
\text { RNAiMAX Reagent) }\end{array}$ & $\begin{array}{l}\text { cycle quiescence; } \\
\text { dormancy; drug } \\
\text { resistance (carboplatin) }\end{array}$ & $\begin{array}{l}\text { A novel therapeutic strategy } \\
\text { to target dormant breast } \\
\text { cancer cells. }\end{array}$ & [85] \\
\hline miR-130a, $425(\downarrow)$ & MCF-7 & & $\begin{array}{c}\text { associated with } \\
\text { the mTOR, ErbB, } \\
\text { MAPK and TGF- } \beta \\
\text { signaling } \\
\text { pathways }\end{array}$ & $\mathrm{DR} \beta-\mathrm{H}$ & cell proliferation & $\begin{array}{l}\text { DR } \beta-H \text { inhibited MCF-7/S } \\
\text { cell growth through reducing } \\
\text { exosome release. }\end{array}$ & [114] \\
\hline miR-128 ( $\downarrow)$ & $\begin{array}{l}\text { Cancer cell } \\
\text { (MCF-7) }\end{array}$ & $\begin{array}{l}\text { Cancer cell } \\
\text { (MCF-7) }\end{array}$ & Bax & Shikonin (SK) & cell proliferation & $\begin{array}{l}\text { shikonin inhibits the } \\
\text { proliferation of MCF-7 cells } \\
\text { by reducing tumor-derived } \\
\text { exosomal miR-128. }\end{array}$ & [115] \\
\hline $\operatorname{miR}-140(\uparrow)$ & $\begin{array}{c}\text { Mouse } \\
\text { preadipocyte } \\
(3 \mathrm{~T} 3 \mathrm{~L} 1, \mathrm{MBA}-1)\end{array}$ & MCF10DCIS cells & SOX9 & Shikonin (SK) & $\begin{array}{l}\text { tumorigenesis; } \\
\text { regulating } \\
\text { differentiation, } \\
\text { stemness, and } \\
\text { migration }\end{array}$ & $\begin{array}{l}\text { (1) MiR-140/SOX2/SOX9 axis } \\
\text { can regulate differentiation, } \\
\text { stemness, and migration. } \\
\text { (2) SK-treated preadipocytes } \\
\text { secrete exosomes with high } \\
\text { levels of miR-140, which can } \\
\text { inhibit nearby DCIS cells by } \\
\text { targeting SOX9 signaling }\end{array}$ & [116] \\
\hline $\operatorname{miR}-16(\uparrow)$ & Cancer cell (4T1) & TAMs (RAW264.7) & & EGCG & TME & $\begin{array}{l}\text { EGCG up-regulates miR-16 in } \\
\text { tumor cells, which can be } \\
\text { transferred to TAM via } \\
\text { exosomes and inhibits TAM } \\
\text { infiltration and M2 } \\
\text { polarization }\end{array}$ & [117] \\
\hline $\begin{array}{l}\text { miR-34a ( }(), \\
\quad 452(\downarrow)\end{array}$ & $\begin{array}{l}\text { Cancer cell } \\
\text { (MCF-7/Doc, } \\
\text { MCF-7/Adr) }\end{array}$ & Cancer cell & & $\beta$-elemene & $\begin{array}{l}\text { reverse drug resistance } \\
\text { (docetaxel, adriamycin) }\end{array}$ & $\begin{array}{l}\beta \text {-elemene effectively } \\
\text { sensitizes drug-resistant BCA } \\
\text { cells to Doc and Adr through } \\
\text { a signaling pathway that } \\
\text { involves miRNA and } \\
\text { gene regulation }\end{array}$ & [118] \\
\hline
\end{tabular}


Table 5. Cont.

\begin{tabular}{|c|c|c|c|c|c|c|c|}
\hline $\begin{array}{l}\text { Therapeutic } \\
\text { Cargo }\end{array}$ & EV Source & Recipient Cells & Target Gene & $\begin{array}{c}\text { Drug Loading } \\
\text { Techniques/POSSIBLE } \\
\text { Drugs }\end{array}$ & Biological Activities & Key Findings & Refs \\
\hline $\operatorname{miR}-23 b, 320 b(\uparrow)$ & $\begin{array}{l}\text { Cancer cell } \\
\text { (MDA-MB-231, } \\
\text { MCF-7, ZR751 } \\
\text { and BT20) }\end{array}$ & $\begin{array}{l}\text { Epithelial cells } \\
\text { (MCF-10A, } \\
\text { EA.hy926) }\end{array}$ & $\begin{array}{l}\text { PLAU, AMOTL1 } \\
\text { (miR-23b); NRP1, } \\
\text { ETS2 (miR-320b) }\end{array}$ & DHA & angiogenesis & $\begin{array}{l}\text { the microRNAs transferred by } \\
\text { exosomes mediate DHA's } \\
\text { anti-angiogenic action. }\end{array}$ & [119] \\
\hline let-7a & $\begin{array}{l}\text { Donor cells } \\
\text { (express the } \\
\text { transmembrane } \\
\text { domain of PDGF } \\
\text { fused to the } \\
\text { GE11 peptide) }\end{array}$ & $\begin{array}{l}\text { EGFR-expressing } \\
\text { breast cancer cells }\end{array}$ & & $\begin{array}{l}\text { Modified exosomes with } \\
\text { the GE11 peptide or } \\
\text { EGF on their surfaces }\end{array}$ & & $\begin{array}{l}\text { (1) Modified exosomes with } \\
\text { the GE11 peptide or EGF on } \\
\text { their surfaces delivered } \\
\text { miRNA to EGFR-expressing } \\
\text { cancer tissues; } \\
\text { (2) intravenously injected } \\
\text { exosomes targeting EGFR } \\
\text { delivered let-7a specifically to } \\
\text { xenograft breast cancer cells } \\
\text { in RAG2 }{ }^{-/} \text {mice. }\end{array}$ & [120] \\
\hline $\operatorname{miR}-379(\uparrow)$ & Engineered MSCs & $\begin{array}{c}\text { Cancer cells (T47D, } \\
\text { HCC-1954) }\end{array}$ & COX-2 & lentiviral transduction & & $\begin{array}{l}\text { Exploiting the tumor-homing } \\
\text { capacity of MSCs while } \\
\text { engineering the cells to secrete } \\
\text { EVs enriched with miR-379 } \\
\text { holds exciting potential as an } \\
\text { innovative therapy for } \\
\text { metastatic breast cancer. }\end{array}$ & [121] \\
\hline $\begin{array}{c}\text { miR-155, }-142 \text {, and } \\
\text { let-7i }(\uparrow)\end{array}$ & Cancer cells (4T1) & Dendritic cells & $\begin{array}{l}\text { IL-6, IL-17, IL-1b, } \\
\text { TGF- } \beta, \text { SOCS1, } \\
\text { KLRK1, IFN- } \gamma, \\
\text { and TLR4 }\end{array}$ & electroporation & & $\begin{array}{l}\text { The modified exosomes } \\
\text { would be a hopeful cell-free } \\
\text { vaccine for cancer treatment. }\end{array}$ & [122] \\
\hline $\begin{array}{l}\text { anti-miR-142-3p } \\
\text { oligonucleotides }\end{array}$ & MSCs & $\begin{array}{l}\text { Cancer cell (4T1 } \\
\text { and TUBO) }\end{array}$ & $\begin{array}{l}\text { APC (miR-142-3p); } \\
\text { P2 × 7R (miR-150) }\end{array}$ & $\begin{array}{l}\text { LNA (locked nucleic } \\
\text { acid)-modified }\end{array}$ & & $\begin{array}{c}\text { MSCs-derived exosomes } \\
\text { could be used as a feasible } \\
\text { nano-vehicle to deliver drug } \\
\text { molecules like } \\
\text { LNA-anti-miR-142-3p in both } \\
\text { in vitro and in vivo studies. }\end{array}$ & [125] \\
\hline
\end{tabular}




\section{Conclusions and Future Perspectives}

In the tumor microenvironment of breast cancer, the powerful regulatory effect of the exosomal miRNA is obvious and true. Tumor cells, especially with the phenotype of malignancy and drug-resistance, would secrete exosomes containing specific miRNAs to non-drug-resistant cancer cells, and even to normal stromal cells. Conversely, macrophages, fibroblasts, and other stromal cells could also transmit the exosomes to the cancer cells, which encouraged the erosion of cancer cells.

Although some progress has been made in this field, and some advanced understandings have arrived, we still face difficulties. For example, there is only little research on the response of exosomes to the changes of physical conditions during the carcinogenesis such as acidity and hypoxia in TME. Additionally, no systematic and accepted method has been found in the separation of the exosomes from plasma or serum yet, which may result in a non-reliable outcome. It is recognized that the clinical use of molecular markers is very demanding. The conversion of exosomal miRNA in the peripheral blood, which is clearly enriched and differentiated in basic scientific research, into a clinical biomarker for diagnosis and detection requires more detailed screening and more support of clinical data. A greater effort needs to be taken to exploit the deeper potential of miRNAs in exosomes, such as revealing their mechanisms in depth, the modification of exosomes, and the development of new clinical treatments.

Author Contributions: This review was conceptualized by all the authors; Q.L. conceived ideas about the microRNAs contained in exosomes and drafted the article; F.P. and J.C. critically reviewed the content; The project and funding were administrated by J.C. All the authors approved to publish the final version.

Funding: This research was funded by Guangxi Science and Technology Key Research and Development Program, No. AB16450008 and National Natural Science Foundation of China, N o. 81573663 NSFC.

Conflicts of Interest: The authors declare no conflict of interest.

\section{References}

1. Cancer Genome Atlas, N. Comprehensive molecular portraits of human breast tumours. Nature 2012, 490, 61-70. [CrossRef] [PubMed]

2. Siegel, R.L.; Miller, K.D.; Jemal, A. Cancer statistics. CA Cancer J. Clin. 2018, 68, 7-30. [CrossRef] [PubMed]

3. DeSantis, C.E.; Ma, J.; Goding Sauer, A.; Newman, L.A.; Jemal, A. Breast cancer statistics, 2017, racial disparity in mortality by state. CA Cancer J. Clin. 2017, 67, 439-448. [CrossRef] [PubMed]

4. Aleskandarany, M.A.; Vandenberghe, M.E.; Marchio, C.; Ellis, I.O.; Sapino, A.; Rakha, E.A. Tumour Heterogeneity of Breast Cancer: From Morphology to Personalised Medicine. Pathobiology 2018, 85, $23-34$. [CrossRef] [PubMed]

5. Curigliano, G.; Burstein, H.J.; P Winer, E.; Gnant, M.; Dubsky, P.; Loibl, S.; Colleoni, M.; Regan, M.M.; Piccart-Gebhart, M.; Senn, H.J.; et al. De-escalating and escalating treatments for early-stage breast cancer: The St. Gallen International Expert Consensus Conference on the Primary Therapy of Early Breast Cancer. Ann. Oncol. 2017, 28, 1700-1712. [CrossRef] [PubMed]

6. Coates, A.S.; Winer, E.P.; Goldhirsch, A.; Gelber, R.D.; Gnant, M.; Piccart-Gebhart, M.; Thurlimann, B.; Senn, H.J.; Panel, M. Tailoring therapies-Improving the management of early breast cancer: St Gallen International Expert Consensus on the Primary Therapy of Early Breast Cancer. Ann. Oncol. 2015, 26, 1533-1546. [CrossRef] [PubMed]

7. Kurozumi, S.; Yamaguchi, Y.; Kurosumi, M.; Ohira, M.; Matsumoto, H.; Horiguchi, J. Recent trends in microRNA research into breast cancer with particular focus on the associations between microRNAs and intrinsic subtypes. J. Hum. Genet. 2017, 62, 15-24. [CrossRef]

8. Elston, C.W.; Ellis, I.O.; Pinder, S.E. Pathological prognostic factors in breast cancer. Crit. Rev.Oncol. Hematol. 1999, 31, 209-223. [CrossRef]

9. Langley, R.R.; Fidler, I.J. The seed and soil hypothesis revisited-The role of tumor-stroma interactions in metastasis to different organs. Int. J. Cancer 2011, 128, 2527-2535. [CrossRef]

10. Ribatti, D.; Mangialardi, G.; Vacca, A. Stephen Paget and the 'seed and soil' theory of metastatic dissemination. Clin. Exp. Med. 2006, 6, 145-149. [CrossRef] 
11. Paget, S.J.T.L. The distribution of secondary growths in cancer of the breast. Lancet 1889, 133, 571-573. [CrossRef]

12. Soysal, S.D.; Tzankov, A.; Muenst, S.E. Role of the Tumor Microenvironment in Breast Cancer. Pathobiology 2015, 82, 142-152. [CrossRef] [PubMed]

13. Suzuki, H.I.; Katsura, A.; Matsuyama, H.; Miyazono, K. MicroRNA regulons in tumor microenvironment. Oncogene 2015, 34, 3085-3094. [CrossRef] [PubMed]

14. Hui, L.; Chen, Y. Tumor microenvironment: Sanctuary of the devil. Cancer Lett. 2015, 368, 7-13. [CrossRef] [PubMed]

15. Kalluri, R.; Zeisberg, M. Fibroblasts in cancer. Nat. Rev. Cancer 2006, 6, 392-401. [CrossRef]

16. Kalluri, R. The biology and function of fibroblasts in cancer. Nat. Rev. Cancer 2016, 16, 582-598. [CrossRef]

17. Liao, Z.; Tan, Z.W.; Zhu, P.; Tan, N.S. Cancer-associated fibroblasts in tumor microenvironment-Accomplices in tumor malignancy. Cell. Immunol. 2018. [CrossRef]

18. Shiga, K.; Hara, M.; Nagasaki, T.; Sato, T.; Takahashi, H.; Takeyama, H. Cancer-Associated Fibroblasts: Their Characteristics and Their Roles in Tumor Growth. Cancers 2015, 7, 2443-2458. [CrossRef]

19. Weber, C.E.; Kothari, A.N.; Wai, P.Y.; Li, N.Y.; Driver, J.; Zapf, M.A.; Franzen, C.A.; Gupta, G.N.; Osipo, C.; Zlobin, A.; et al. Osteopontin mediates an MZF1-TGF-beta1-dependent transformation of mesenchymal stem cells into cancer-associated fibroblasts in breast cancer. Oncogene 2015, 34, 4821-4833. [CrossRef]

20. McDonald, L.T.; LaRue, A.C. Hematopoietic stem cell derived carcinoma-associated fibroblasts: A novel origin. Int. J. Clin. Exp. Pathol. 2012, 5, 863.

21. Orimo, A.; Gupta, P.B.; Sgroi, D.C.; Arenzana-Seisdedos, F.; Delaunay, T.; Naeem, R.; Carey, V.J.; Richardson, A.L.; Weinberg, R.A. Stromal fibroblasts present in invasive human breast carcinomas promote tumor growth and angiogenesis through elevated SDF-1/CXCL12 secretion. Cell 2005, 121, 335-348. [CrossRef] [PubMed]

22. Nagasaki, T.; Hara, M.; Nakanishi, H.; Takahashi, H.; Sato, M.; Takeyama, H. Interleukin-6 released by colon cancer-associated fibroblasts is critical for tumour angiogenesis: Anti-interleukin- 6 receptor antibody suppressed angiogenesis and inhibited tumour-stroma interaction. Br. J. Cancer 2014, 110, 469-478. [CrossRef] [PubMed]

23. Giulianelli, S.; Cerliani, J.P.; Lamb, C.A.; Fabris, V.T.; Bottino, M.C.; Gorostiaga, M.A.; Novaro, V.; Gongora, A.; Baldi, A.; Molinolo, A.; et al. Carcinoma-associated fibroblasts activate progesterone receptors and induce hormone independent mammary tumor growth: A role for the FGF-2/FGFR-2 axis. Int. J. Cancer 2008, 123, 2518-2531. [CrossRef] [PubMed]

24. Radisky, E.S.; Radisky, D.C. Stromal induction of breast cancer: Inflammation and invasion. Rev. Endocr. Metab. Disord. 2007, 8, 279-287. [CrossRef] [PubMed]

25. Kohlhapp, F.J.; Mitra, A.K.; Lengyel, E.; Peter, M.E. MicroRNAs as mediators and communicators between cancer cells and the tumor microenvironment. Oncogene 2015, 34, 5857-5868. [CrossRef] [PubMed]

26. Balkwill, F.R.; Capasso, M.; Hagemann, T. The tumor microenvironment at a glance. J. Cell Sci. 2012, 125, 5591-5596. [CrossRef] [PubMed]

27. Mantovani, A.; Marchesi, F.; Malesci, A.; Laghi, L.; Allavena, P. Tumour-associated macrophages as treatment targets in oncology. Nat. Rev. Clin. Oncol. 2017, 14, 399-416. [CrossRef] [PubMed]

28. Noy, R.; Pollard, J.W. Tumor-associated macrophages: From mechanisms to therapy. Immunity 2014, 41, 49-61. [CrossRef] [PubMed]

29. Williams, C.B.; Yeh, E.S.; Soloff, A.C. Tumor-associated macrophages: Unwitting accomplices in breast cancer malignancy. NPJ Breast Cancer 2016, 2. [CrossRef]

30. Lim, B.; Woodward, W.A.; Wang, X.; Reuben, J.M.; Ueno, N.T. Inflammatory breast cancer biology: The tumour microenvironment is key. Nat. Rev. Cancer 2018, 18, 485-499. [CrossRef]

31. Green, T.M.; Alpaugh, M.L.; Barsky, S.H.; Rappa, G.; Lorico, A. Breast Cancer-Derived Extracellular Vesicles: Characterization and Contribution to the Metastatic Phenotype. BioMed Res. Int. 2015, 2015, 634865. [CrossRef] [PubMed]

32. Wang, M.; Yu, F.; Ding, H.; Wang, Y.; Li, P.; Wang, K. Emerging Function and Clinical Values of Exosomal MicroRNAs in Cancer. Mol. Ther. Nucleic. Acids 2019, 16, 791-804. [CrossRef] [PubMed]

33. Sempere, L.F.; Keto, J.; Fabbri, M. Exosomal MicroRNAs in Breast Cancer towards Diagnostic and Therapeutic Applications. Cancers 2017, 9, 71. [CrossRef] [PubMed] 
34. Kharaziha, P.; Ceder, S.; Li, Q.; Panaretakis, T. Tumor cell-derived exosomes: A message in a bottle. Biochim. Biophys. Acta 2012, 1826, 103-111. [CrossRef] [PubMed]

35. Hannafon, B.N.; Ding, W.Q. Intercellular communication by exosome-derived microRNAs in cancer. Int. J. Mol. Sci. 2013, 14, 14240-14269. [CrossRef]

36. Xu, R.; Rai, A.; Chen, M.; Suwakulsiri, W.; Greening, D.W.; Simpson, R.J. Extracellular vesicles in cancer-Implications for future improvements in cancer care. Nat. Rev. Clin. Oncol. 2018, 15, 617-638. [CrossRef] [PubMed]

37. Mulcahy, L.A.; Pink, R.C.; Carter, D.R. Routes and mechanisms of extracellular vesicle uptake. J. Extracell. Vesicles 2014, 3, 24641. [CrossRef]

38. Meng, Y.; Sun, J.; Wang, X.; Hu, T.; Ma, Y.; Kong, C.; Piao, H.; Yu, T.; Zhang, G. Exosomes: A Promising Avenue for the Diagnosis of Breast Cancer. Technol. Cancer Res. Treat. 2019, 18, 1533033818821421. [CrossRef]

39. Bahrami, A.; Aledavood, A.; Anvari, K.; Hassanian, S.M.; Maftouh, M.; Yaghobzade, A.; Salarzaee, O.; ShahidSales, S.; Avan, A. The prognostic and therapeutic application of microRNAs in breast cancer: Tissue and circulating microRNAs. J. Cell. Physiol. 2018, 233, 774-786. [CrossRef]

40. Record, M. Intercellular communication by exosomes in placenta: A possible role in cell fusion? Placenta 2014, 35, 297-302. [CrossRef]

41. Teng, X.; Chen, L.; Chen, W.; Yang, J.; Yang, Z.; Shen, Z. Mesenchymal Stem Cell-Derived Exosomes Improve the Microenvironment of Infarcted Myocardium Contributing to Angiogenesis and Anti-Inflammation. Cell. Physiol. Biochem. 2015, 37, 2415-2424. [CrossRef] [PubMed]

42. Greening, D.W.; Nguyen, H.P.; Elgass, K.; Simpson, R.J.; Salamonsen, L.A. Human Endometrial Exosomes Contain Hormone-Specific Cargo Modulating Trophoblast Adhesive Capacity: Insights into Endometrial-Embryo Interactions. Biol. Reprod. 2016, 94, 38. [CrossRef] [PubMed]

43. Di Ieva, A.; Butz, H.; Niamah, M.; Rotondo, F.; De Rosa, S.; Sav, A.; Yousef, G.M.; Kovacs, K.; Cusimano, M.D. MicroRNAs as biomarkers in pituitary tumors. Neurosurgery 2014, 75, 181-189. [CrossRef] [PubMed]

44. Lee, R.C.; Feinbaum, R.L.; Ambros, V.J. The C. elegans heterochronic gene lin-4 encodes small RNAs with antisense complementarity to lin-14. Cell 1993, 1993, 843-854. [CrossRef]

45. Berindan-Neagoe, I.; Monroig Pdel, C.; Pasculli, B.; Calin, G.A. MicroRNAome genome: A treasure for cancer diagnosis and therapy. CA Cancer J. Clin. 2014, 64, 311-336. [CrossRef] [PubMed]

46. Li, Z.; Rana, T.M. Therapeutic targeting of microRNAs: Current status and future challenges. Nat. Rev. Drug Discov. 2014, 13, 622-638. [CrossRef]

47. Challagundla, K.B.; Fanini, F.; Vannini, I.; Wise, P.; Murtadha, M.; Malinconico, L.; Cimmino, A.; Fabbri, M. microRNAs in the tumor microenvironment: Solving the riddle for a better diagnostics. Expert Rev. Mol. Diagn. 2014, 14, 565-574. [CrossRef]

48. Zhang, H.; Li, Y.; Lai, M. The microRNA network and tumor metastasis. Oncogene 2010, 29, 937-948. [CrossRef]

49. Huang, Q.; Gumireddy, K.; Schrier, M.; le Sage, C.; Nagel, R.; Nair, S.; Egan, D.A.; Li, A.; Huang, G.; Klein-Szanto, A.J.; et al. The microRNAs miR-373 and miR-520c promote tumour invasion and metastasis. Nat. Cell Biol. 2008, 10, 202-210. [CrossRef]

50. Zhong, S.; Chen, X.; Wang, D.; Zhang, X.; Shen, H.; Yang, S.; Lv, M.; Tang, J.; Zhao, J. MicroRNA expression profiles of drug-resistance breast cancer cells and their exosomes. Oncotarget 2016, 7, 19601-19609. [CrossRef]

51. Chen, W.X.; Xu, L.Y.; Qian, Q.; He, X.; Peng, W.T.; Zhu, Y.L.; Cheng, L. Analysis of miRNA signature differentially expressed in exosomes from adriamycin-resistant and parental human breast cancer cells. Biosci. Rep. 2018, 38. [CrossRef] [PubMed]

52. Guzman, N.; Agarwal, K.; Asthagiri, D.; Yu, L.; Saji, M.; Ringel, M.D.; Paulaitis, M.E. Breast Cancer-Specific miR Signature Unique to Extracellular Vesicles Includes "microRNA-like" tRNA Fragments. Mol. Cancer Res. MCR 2015, 13, 891-901. [CrossRef] [PubMed]

53. Kruger, S.; Abd Elmageed, Z.Y.; Hawke, D.H.; Worner, P.M.; Jansen, D.A.; Abdel-Mageed, A.B.; Alt, E.U.; Izadpanah, R. Molecular characterization of exosome-like vesicles from breast cancer cells. BMC Cancer 2014, 14, 44. [CrossRef] [PubMed]

54. Stevic, I.; Muller, V.; Weber, K.; Fasching, P.A.; Karn, T.; Marme, F.; Schem, C.; Stickeler, E.; Denkert, C.; van Mackelenbergh, M.; et al. Specific microRNA signatures in exosomes of triple-negative and HER2-positive breast cancer patients undergoing neoadjuvant therapy within the GeparSixto trial. BMC Med. 2018, 16, 179. [CrossRef] [PubMed] 
55. Fish, E.J.; Irizarry, K.J.; DeInnocentes, P.; Ellis, C.J.; Prasad, N.; Moss, A.G.; Curt Bird, R. Malignant canine mammary epithelial cells shed exosomes containing differentially expressed microRNA that regulate oncogenic networks. BMC Cancer 2018, 18, 832. [CrossRef] [PubMed]

56. Liu, T.; Zhang, Q.; Zhang, J.; Li, C.; Miao, Y.R.; Lei, Q.; Li, Q.; Guo, A.Y. EVmiRNA: A database of miRNA profiling in extracellular vesicles. Nucleic Acids Res. 2019, 47, D89-D93. [CrossRef] [PubMed]

57. Melo, S.A.; Sugimoto, H.; O'Connell, J.T.; Kato, N.; Villanueva, A.; Vidal, A.; Qiu, L.; Vitkin, E.; Perelman, L.T.; Melo, C.A.; et al. Cancer exosomes perform cell-independent microRNA biogenesis and promote tumorigenesis. Cancer Cell 2014, 26, 707-721. [CrossRef] [PubMed]

58. Kosaka, N.; Iguchi, H.; Hagiwara, K.; Yoshioka, Y.; Takeshita, F.; Ochiya, T. Neutral sphingomyelinase 2 (nSMase2)-dependent exosomal transfer of angiogenic microRNAs regulate cancer cell metastasis. J. Biol. Chem. 2013, 288, 10849-10859. [CrossRef] [PubMed]

59. Singh, R.; Pochampally, R.; Watabe, K.; Lu, Z.; Mo, Y.Y. Exosome-mediated transfer of miR-10b promotes cell invasion in breast cancer. Mol. Cancer 2014, 13, 256. [CrossRef]

60. Ma, L.; Teruya-Feldstein, J.; Weinberg, R.A. Tumour invasion and metastasis initiated by microRNA-10b in breast cancer. Nature 2007, 449, 682-688. [CrossRef]

61. Li, X.J.; Ren, Z.J.; Tang, J.H.; Yu, Q. Exosomal MicroRNA MiR-1246 Promotes Cell Proliferation, Invasion and Drug Resistance by Targeting CCNG2 in Breast Cancer. Cell. Physiol. Biochem. 2017, 44, 1741-1748. [CrossRef] [PubMed]

62. Wei, Y.; Lai, X.; Yu, S.; Chen, S.; Ma, Y.; Zhang, Y.; Li, H.; Zhu, X.; Yao, L.; Zhang, J. Exosomal miR-221/222 enhances tamoxifen resistance in recipient ER-positive breast cancer cells. Breast Cancer Res. Treat. 2014, 147, 423-431. [CrossRef] [PubMed]

63. Yu, D.D.; Wu, Y.; Zhang, X.H.; Lv, M.M.; Chen, W.X.; Chen, X.; Yang, S.J.; Shen, H.; Zhong, S.L.; Tang, J.H.; et al. Exosomes from adriamycin-resistant breast cancer cells transmit drug resistance partly by delivering miR-222. Tumour Biol. 2016, 37, 3227-3235. [CrossRef] [PubMed]

64. Chen, W.X.; Cai, Y.Q.; Lv, M.M.; Chen, L.; Zhong, S.L.; Ma, T.F.; Zhao, J.H.; Tang, J.H. Exosomes from docetaxel-resistant breast cancer cells alter chemosensitivity by delivering microRNAs. Tumour Biol. 2014, 35, 9649-9659. [CrossRef] [PubMed]

65. Chen, W.X.; Liu, X.M.; Lv, M.M.; Chen, L.; Zhao, J.H.; Zhong, S.L.; Ji, M.H.; Hu, Q.; Luo, Z.; Wu, J.Z.; et al. Exosomes from drug-resistant breast cancer cells transmit chemoresistance by a horizontal transfer of microRNAs. PLoS ONE 2014, 9, e95240. [CrossRef] [PubMed]

66. Mao, L.; Li, J.; Chen, W.X.; Cai, Y.Q.; Yu, D.D.; Zhong, S.L.; Zhao, J.H.; Zhou, J.W.; Tang, J.H. Exosomes decrease sensitivity of breast cancer cells to adriamycin by delivering microRNAs. Tumour Biol. 2016, 37, 5247-5256. [CrossRef] [PubMed]

67. Kia, V.; Paryan, M.; Mortazavi, Y.; Biglari, A.; Mohammadi-Yeganeh, S. Evaluation of exosomal miR-9 and miR-155 targeting PTEN and DUSP14 in highly metastatic breast cancer and their effect on low metastatic cells. J. Cell. Biochem. 2019, 120, 5666-5676. [CrossRef]

68. Kia, V.; Mortazavi, Y.; Paryan, M.; Biglari, A.; Mohammadi-Yeganeh, S. Exosomal miRNAs from highly metastatic cells can induce metastasis in non-metastatic cells. Life Sci. 2019, 220, 162-168. [CrossRef]

69. Mihelich, B.L.; Dambal, S.; Lin, S.; Nonn, L. miR-182, of the miR-183 cluster family, is packaged in exosomes and is detected in human exosomes from serum, breast cells and prostate cells. Oncol. Lett. 2016, 12, 1197-1203. [CrossRef]

70. O’Brien, K.; Lowry, M.C.; Corcoran, C.; Martinez, V.G.; Daly, M.; Rani, S.; Gallagher, W.M.; Radomski, M.W.; MacLeod, R.A.; O'Driscoll, L. miR-134 in extracellular vesicles reduces triple-negative breast cancer aggression and increases drug sensitivity. Oncotarget 2015, 6, 32774-32789. [CrossRef]

71. Zhou, W.; Fong, M.Y.; Min, Y.; Somlo, G.; Liu, L.; Palomares, M.R.; Yu, Y.; Chow, A.; O'Connor, S.T.; Chin, A.R.; et al. Cancer-secreted miR-105 destroys vascular endothelial barriers to promote metastasis. Cancer Cell 2014, 25, 501-515. [CrossRef] [PubMed]

72. Di Modica, M.; Regondi, V.; Sandri, M.; Iorio, M.V.; Zanetti, A.; Tagliabue, E.; Casalini, P.; Triulzi, T. Breast cancer-secreted miR-939 downregulates VE-cadherin and destroys the barrier function of endothelial monolayers. Cancer Lett. 2017, 384, 94-100. [CrossRef] [PubMed]

73. Yan, W.; Wu, X.; Zhou, W.; Fong, M.Y.; Cao, M.; Liu, J.; Liu, X.; Chen, C.H.; Fadare, O.; Pizzo, D.P.; et al. Cancer-cell-secreted exosomal miR-105 promotes tumour growth through the MYC-dependent metabolic reprogramming of stromal cells. Nat. Cell Biol. 2018, 20, 597-609. [CrossRef] [PubMed] 
74. Fong, M.Y.; Zhou, W.; Liu, L.; Alontaga, A.Y.; Chandra, M.; Ashby, J.; Chow, A.; O'Connor, S.T.; Li, S.; Chin, A.R.; et al. Breast-cancer-secreted miR-122 reprograms glucose metabolism in premetastatic niche to promote metastasis. Nat. Cell Biol. 2015, 17, 183-194. [CrossRef] [PubMed]

75. Hashimoto, K.; Ochi, H.; Sunamura, S.; Kosaka, N.; Mabuchi, Y.; Fukuda, T.; Yao, K.; Kanda, H.; Ae, K.; Okawa, A.; et al. Cancer-secreted hsa-miR-940 induces an osteoblastic phenotype in the bone metastatic microenvironment via targeting ARHGAP1 and FAM134A. Proc. Natl. Acad. Sci. USA 2018, 115, 2204-2209. [CrossRef] [PubMed]

76. Li, Y.; Liang, Y.; Sang, Y.; Song, X.; Zhang, H.; Liu, Y.; Jiang, L.; Yang, Q. MiR-770 suppresses the chemo-resistance and metastasis of triple negative breast cancer via direct targeting of STMN. Cell Death Dis. 2018, 9, 14. [CrossRef] [PubMed]

77. Vaupel, P.; Mayer, A. Hypoxia in cancer: Significance and impact on clinical outcome. Cancer Metastasis Rev. 2007, 26, 225-239. [CrossRef] [PubMed]

78. Jung, K.O.; Youn, H.; Lee, C.H.; Kang, K.W.; Chung, J.K. Visualization of exosome-mediated miR-210 transfer from hypoxic tumor cells. Oncotarget 2017, 8, 9899-9910. [CrossRef] [PubMed]

79. King, H.W.; Michael, M.Z.; Gleadle, J.M. Hypoxic enhancement of exosome release by breast cancer cells. BMC Cancer 2012, 12, 421. [CrossRef] [PubMed]

80. Baroni, S.; Romero-Cordoba, S.; Plantamura, I.; Dugo, M.; D’Ippolito, E.; Cataldo, A.; Cosentino, G.; Angeloni, V.; Rossini, A.; Daidone, M.G.; et al. Exosome-mediated delivery of miR-9 induces cancer-associated fibroblast-like properties in human breast fibroblasts. Cell Death Dis. 2016, 7, e2312. [CrossRef] [PubMed]

81. Dioufa, N.; Clark, A.M.; Ma, B.; Beckwitt, C.H.; Wells, A. Bi-directional exosome-driven intercommunication between the hepatic niche and cancer cells. Mol. Cancer 2017, 16, 172. [CrossRef] [PubMed]

82. Ono, M.; Kosaka, N.; Tominaga, N.; Yoshioka, Y.; Takeshita, F.; Takahashi, R.U.; Yoshida, M.; Tsuda, H.; Tamura, K.; Ochiya, T. Exosomes from bone marrow mesenchymal stem cells contain a microRNA that promotes dormancy in metastatic breast cancer cells. Sci. Signal. 2014, 7, ra63. [CrossRef] [PubMed]

83. Uen, Y.; Wang, J.W.; Wang, C.; Jhang, Y.; Chung, J.Y.; Tseng, T.; Sheu, M.; Lee, S. Mining of potential microRNAs with clinical correlation-Regulation of syndecan-1 expression by miR-122-5p altered mobility of breast cancer cells and possible correlation with liver injury. Oncotarget 2018, 9, 28165-28175. [CrossRef] [PubMed]

84. Santos, J.C.; Lima, N.D.S.; Sarian, L.O.; Matheu, A.; Ribeiro, M.L.; Derchain, S.F.M. Exosome-mediated breast cancer chemoresistance via miR-155 transfer. Sci. Rep. 2018, 8, 829. [CrossRef] [PubMed]

85. Bliss, S.A.; Sinha, G.; Sandiford, O.A.; Williams, L.M.; Engelberth, D.J.; Guiro, K.; Isenalumhe, L.L.; Greco, S.J.; Ayer, S.; Bryan, M.; et al. Mesenchymal Stem Cell-Derived Exosomes Stimulate Cycling Quiescence and Early Breast Cancer Dormancy in Bone Marrow. Cancer Res. 2016, 76, 5832-5844. [CrossRef] [PubMed]

86. Lim, P.K.; Bliss, S.A.; Patel, S.A.; Taborga, M.; Dave, M.A.; Gregory, L.A.; Greco, S.J.; Bryan, M.; Patel, P.S.; Rameshwar, P. Gap junction-mediated import of microRNA from bone marrow stromal cells can elicit cell cycle quiescence in breast cancer cells. Cancer Res. 2011, 71, 1550-1560. [CrossRef]

87. Vallabhaneni, K.C.; Penfornis, P.; Dhule, S.; Guillonneau, F.; Adams, K.V.; Mo, Y.Y.; Xu, R.; Liu, Y.; Watabe, K.; Vemuri, M.C.; et al. Extracellular vesicles from bone marrow mesenchymal stem/stromal cells transport tumor regulatory microRNA, proteins, and metabolites. Oncotarget 2015, 6, 4953-4967. [CrossRef]

88. Deng, Z.; Rong, Y.; Teng, Y.; Zhuang, X.; Samykutty, A.; Mu, J.; Zhang, L.; Cao, P.; Yan, J.; Miller, D.; et al. Exosomes miR-126a released from MDSC induced by DOX treatment promotes lung metastasis. Oncogene 2017, 36, 639-651. [CrossRef]

89. Shah, S.H.; Miller, P.; Garcia-Contreras, M.; Ao, Z.; Machlin, L.; Issa, E.; El-Ashry, D. Hierarchical paracrine interaction of breast cancer associated fibroblasts with cancer cells via hMAPK-microRNAs to drive ER-negative breast cancer phenotype. Cancer Biol. Ther. 2015, 16, 1671-1681. [CrossRef]

90. Donnarumma, E.; Fiore, D.; Nappa, M.; Roscigno, G.; Adamo, A.; Iaboni, M.; Russo, V.; Affinito, A.; Puoti, I.; Quintavalle, C.; et al. Cancer-associated fibroblasts release exosomal microRNAs that dictate an aggressive phenotype in breast cancer. Oncotarget 2017, 8, 19592-19608. [CrossRef]

91. Yang, M.; Chen, J.; Su, F.; Yu, B.; Su, F.; Lin, L.; Liu, Y.; Huang, J.D.; Song, E. Microvesicles secreted by macrophages shuttle invasion-potentiating microRNAs into breast cancer cells. Mol. Cancer 2011, 10, 117. [CrossRef] 
92. Lee, J.K.; Park, S.R.; Jung, B.K.; Jeon, Y.K.; Lee, Y.S.; Kim, M.K.; Kim, Y.G.; Jang, J.Y.; Kim, C.W. Exosomes derived from mesenchymal stem cells suppress angiogenesis by down-regulating VEGF expression in breast cancer cells. PLoS ONE 2013, 8, e84256. [CrossRef] [PubMed]

93. Pakravan, K.; Babashah, S.; Sadeghizadeh, M.; Mowla, S.J.; Mossahebi-Mohammadi, M.; Ataei, F.; Dana, N.; Javan, M. MicroRNA-100 shuttled by mesenchymal stem cell-derived exosomes suppresses in vitro angiogenesis through modulating the mTOR/HIF-1alpha/VEGF signaling axis in breast cancer cells. Cell. Oncol. 2017, 40, 457-470. [CrossRef] [PubMed]

94. Bovy, N.; Blomme, B.; Freres, P.; Dederen, S.; Nivelles, O.; Lion, M.; Carnet, O.; Martial, J.A.; Noel, A.; Thiry, M.; et al. Endothelial exosomes contribute to the antitumor response during breast cancer neoadjuvant chemotherapy via microRNA transfer. Oncotarget 2015, 6, 10253-10266. [CrossRef] [PubMed]

95. Li, M.; Zhou, Y.; Xia, T.; Zhou, X.; Huang, Z.; Zhang, H.; Zhu, W.; Ding, Q.; Wang, S. Circulating microRNAs from the miR-106a-363 cluster on chromosome $\mathrm{X}$ as novel diagnostic biomarkers for breast cancer. Breast Cancer Res. Treat. 2018, 170, 257-270. [CrossRef] [PubMed]

96. Hannafon, B.N.; Trigoso, Y.D.; Calloway, C.L.; Zhao, Y.D.; Lum, D.H.; Welm, A.L.; Zhao, Z.J.; Blick, K.E.; Dooley, W.C.; Ding, W.Q. Plasma exosome microRNAs are indicative of breast cancer. Breast Cancer Res. BCR 2016, 18, 90. [CrossRef] [PubMed]

97. Eichelser, C.; Stuckrath, I.; Muller, V.; Milde-Langosch, K.; Wikman, H.; Pantel, K.; Schwarzenbach, H. Increased serum levels of circulating exosomal microRNA-373 in receptor-negative breast cancer patients. Oncotarget 2014, 5, 9650-9663. [CrossRef]

98. Gao, S.; Wang, Y.; Wang, M.; Li, Z.; Zhao, Z.; Wang, R.X.; Wu, R.; Yuan, Z.; Cui, R.; Jiao, K.; et al. MicroRNA-155, induced by FOXP3 through transcriptional repression of BRCA1, is associated with tumor initiation in human breast cancer. Oncotarget 2017, 8, 41451-41464. [CrossRef]

99. Kong, X.; Zhang, J.; Li, J.; Shao, J.; Fang, L. MiR-130a-3p inhibits migration and invasion by regulating RAB5B in human breast cancer stem cell-like cells. Biochem. Biophys. Res. Commun. 2018, 501, 486-493. [CrossRef]

100. Ni, Q.; Stevic, I.; Pan, C.; Muller, V.; Oliviera-Ferrer, L.; Pantel, K.; Schwarzenbach, H. Different signatures of miR-16, miR-30b and miR-93 in exosomes from breast cancer and DCIS patients. Sci. Rep. 2018, 8, 12974. [CrossRef]

101. Zhang, G.; Zhang, W.; Li, B.; Stringer-Reasor, E.; Chu, C.; Sun, L.; Bae, S.; Chen, D.; Wei, S.; Jiao, K.; et al. MicroRNA-200c and microRNA-141 are regulated by a FOXP3-KAT2B axis and associated with tumor metastasis in breast cancer. Breast Cancer Res. BCR 2017, 19, 73. [CrossRef] [PubMed]

102. Yoshikawa, M.; Iinuma, H.; Umemoto, Y.; Yanagisawa, T.; Matsumoto, A.; Jinno, H. Exosome-encapsulated microRNA-223-3p as a minimally invasive biomarker for the early detection of invasive breast cancer. Oncol. Lett. 2018, 15, 9584-9592. [CrossRef] [PubMed]

103. Rodriguez-Martinez, A.; de Miguel-Perez, D.; Ortega, F.G.; Garcia-Puche, J.L.; Robles-Fernandez, I.; Exposito, J.; Martorell-Marugan, J.; Carmona-Saez, P.; Garrido-Navas, M.D.C.; Rolfo, C.; et al. Exosomal miRNA profile as complementary tool in the diagnostic and prediction of treatment response in localized breast cancer under neoadjuvant chemotherapy. Breast Cancer Res. BCR 2019, 21, 21. [CrossRef] [PubMed]

104. Sueta, A.; Yamamoto, Y.; Tomiguchi, M.; Takeshita, T.; Yamamoto-Ibusuki, M.; Iwase, H. Differential expression of exosomal miRNAs between breast cancer patients with and without recurrence. Oncotarget 2017, 8, 69934-69944. [CrossRef] [PubMed]

105. Zhao, Q.; Deng, S.; Wang, G.; Liu, C.; Meng, L.; Qiao, S.; Shen, L.; Zhang, Y.; Lu, J.; Li, W.; et al. A direct quantification method for measuring plasma MicroRNAs identified potential biomarkers for detecting metastatic breast cancer. Oncotarget 2016, 7, 21865-21874. [CrossRef] [PubMed]

106. Zhai, L.Y.; Li, M.X.; Pan, W.L.; Chen, Y.; Li, M.M.; Pang, J.X.; Zheng, L.; Chen, J.X.; Duan, W.J. In Situ Detection of Plasma Exosomal MicroRNA-1246 for Breast Cancer Diagnostics by a Au Nanoflare Probe. ACS Appl. Mater. Interfaces 2018, 10, 39478-39486. [CrossRef]

107. Zhang, J.; Wang, L.L.; Hou, M.F.; Xia, Y.K.; He, W.H.; Yan, A.; Weng, Y.P.; Zeng, L.P.; Chen, J.H. A ratiometric electrochemical biosensor for the exosomal microRNAs detection based on bipedal DNA walkers propelled by locked nucleic acid modified toehold mediate strand displacement reaction. Biosens. Bioelectron. 2018, 102, 33-40. [CrossRef]

108. Sina, A.A.; Vaidyanathan, R.; Wuethrich, A.; Carrascosa, L.G.; Trau, M. Label-free detection of exosomes using a surface plasmon resonance biosensor. Anal. Bioanal. Chem. 2019, 411, 1311-1318. [CrossRef] 
109. Lee, J.H.; Kim, J.A.; Kwon, M.H.; Kang, J.Y.; Rhee, W.J. In Situ single step detection of exosome microRNA using molecular beacon. Biomaterials 2015, 54, 116-125. [CrossRef]

110. Lee, J.H.; Kim, J.A.; Jeong, S.; Rhee, W.J. Simultaneous and multiplexed detection of exosome microRNAs using molecular beacons. Biosens. Bioelectron. 2016, 86, 202-210. [CrossRef]

111. Shao, G.; Ji, S.; Wu, A.; Liu, C.; Wang, M.; Zhang, P.; Jiao, Q.; Kang, Y. DNAzyme-based probe for circulating microRNA detection in peripheral blood. Drug Des. Dev. Ther. 2015, 9, 6109-6117. [CrossRef]

112. Koumangoye, R.B.; Sakwe, A.M.; Goodwin, J.S.; Patel, T.; Ochieng, J. Detachment of breast tumor cells induces rapid secretion of exosomes which subsequently mediate cellular adhesion and spreading. PLoS ONE 2011, 6, e24234. [CrossRef] [PubMed]

113. Manri, C.; Yokoi, T.; Nishida, H. Size-Selective Harvesting of Extracellular Vesicles for Strategic Analyses Towards Tumor Diagnoses. Appl. Biochem. Biotechnol. 2017, 182, 609-623. [CrossRef] [PubMed]

114. Chen, W.X.; Cheng, L.; Pan, M.; Qian, Q.; Zhu, Y.L.; Xu, L.Y.; Ding, Q. D Rhamnose beta-Hederin against human breast cancer by reducing tumor-derived exosomes. Oncol. Lett. 2018, 16, 5172-5178. [CrossRef] [PubMed]

115. Wei, Y.; Li, M.; Cui, S.; Wang, D.; Zhang, C.Y.; Zen, K.; Li, L. Shikonin Inhibits the Proliferation of Human Breast Cancer Cells by Reducing Tumor-Derived Exosomes. Molecules 2016, 21, 777. [CrossRef] [PubMed]

116. Gernapudi, R.; Yao, Y.; Zhang, Y.; Wolfson, B.; Roy, S.; Duru, N.; Eades, G.; Yang, P.; Zhou, Q. Targeting exosomes from preadipocytes inhibits preadipocyte to cancer stem cell signaling in early-stage breast cancer. Breast Cancer Res. Treat. 2015, 150, 685-695. [CrossRef] [PubMed]

117. Jang, J.Y.; Lee, J.K.; Jeon, Y.K.; Kim, C.W. Exosome derived from epigallocatechin gallate treated breast cancer cells suppresses tumor growth by inhibiting tumor-associated macrophage infiltration and M2 polarization. BMC Cancer 2013, 13, 421. [CrossRef] [PubMed]

118. Zhang, J.; Zhang, H.D.; Yao, Y.F.; Zhong, S.L.; Zhao, J.H.; Tang, J.H. beta-Elemene Reverses Chemoresistance of Breast Cancer Cells by Reducing Resistance Transmission via Exosomes. Cell. Physiol. Biochem. 2015, 36, 2274-2286. [CrossRef]

119. Hannafon, B.N.; Carpenter, K.J.; Berry, W.L.; Janknecht, R.; Dooley, W.C.; Ding, W.Q. Exosome-mediated microRNA signaling from breast cancer cells is altered by the anti-angiogenesis agent docosahexaenoic acid (DHA). Mol. Cancer 2015, 14, 133. [CrossRef]

120. Ohno, S.; Takanashi, M.; Sudo, K.; Ueda, S.; Ishikawa, A.; Matsuyama, N.; Fujita, K.; Mizutani, T.; Ohgi, T.; Ochiya, T.; et al. Systemically injected exosomes targeted to EGFR deliver antitumor microRNA to breast cancer cells. Mol. Ther. 2013, 21, 185-191. [CrossRef]

121. O’Brien, K.P.; Khan, S.; Gilligan, K.E.; Zafar, H.; Lalor, P.; Glynn, C.; O'Flatharta, C.; Ingoldsby, H.; Dockery, P.; De Bhulbh, A.; et al. Employing mesenchymal stem cells to support tumor-targeted delivery of extracellular vesicle (EV)-encapsulated microRNA-379. Oncogene 2018, 37, 2137-2149. [CrossRef] [PubMed]

122. Taghikhani, A.; Hassan, Z.M.; Ebrahimi, M.; Moazzeni, S.M. microRNA modified tumor-derived exosomes as novel tools for maturation of dendritic cells. J. Cell. Physiol. 2018, 234, 9417-9427. [CrossRef] [PubMed]

123. Lamichhane, T.N.; Jeyaram, A.; Patel, D.B.; Parajuli, B.; Livingston, N.K.; Arumugasaamy, N.; Schardt, J.S.; Jay, S.M. Oncogene Knockdown via Active Loading of Small RNAs into Extracellular Vesicles by Sonication. Cell. Mol. Bioeng. 2016, 9, 315-324. [CrossRef] [PubMed]

124. Roma-Rodrigues, C.; Pereira, F.; Alves de Matos, A.P.; Fernandes, M.; Baptista, P.V.; Fernandes, A.R. Smuggling gold nanoparticles across cell types-A new role for exosomes in gene silencing. Nanomed. Nanotechnol. Biol. Med. 2017, 13, 1389-1398. [CrossRef] [PubMed]

125. Naseri, Z.; Oskuee, R.K.; Jaafari, M.R.; Forouzandeh Moghadam, M. Exosome-mediated delivery of functionally active miRNA-142-3p inhibitor reduces tumorigenicity of breast cancer in vitro and in vivo. Int. J. Nanomed. 2018, 13, 7727-7747. [CrossRef] [PubMed]

(C) 2019 by the authors. Licensee MDPI, Basel, Switzerland. This article is an open access article distributed under the terms and conditions of the Creative Commons Attribution (CC BY) license (http://creativecommons.org/licenses/by/4.0/). 